$11-22-2010$

\title{
Testing Mechanisms of Subduction Zone Segmentation and Seismogenesis With Slip Distributions From Recent Andean Earthquakes
}

John P. Loveless

Smith College, jloveles@smith.edu

M. E. Pritchard

Cornell University

K. Kukowski

Helmholtz Zentrum Potsdam

Follow this and additional works at: https://scholarworks.smith.edu/geo_facpubs

Part of the Geology Commons

\section{Recommended Citation}

Loveless, John P.; Pritchard, M. E.; and Kukowski, K., "Testing Mechanisms of Subduction Zone Segmentation and Seismogenesis With Slip Distributions From Recent Andean Earthquakes" (2010). Geosciences: Faculty Publications, Smith College, Northampton, MA.

https://scholarworks.smith.edu/geo_facpubs/2

This Article has been accepted for inclusion in Geosciences: Faculty Publications by an authorized administrator of Smith ScholarWorks. For more information, please contact scholarworks@smith.edu 


\title{
Testing mechanisms of subduction zone
}

segmentation and seismogenesis with slip

\section{distributions from recent Andean earthquakes}

\author{
J. P. Loveless ${ }^{\text {a }}$ \\ ${ }^{a}$ Department of Earth and Planetary Sciences, Harvard University, 20 Oxford \\ Street, Cambridge, MA 02138,USA. (loveless@eps.harvard.edu)
}

M. E. Pritchard ${ }^{b}$

${ }^{\mathrm{b}}$ Department of Earth and Atmospheric Sciences, Cornell University, Snee Hall, Ithaca, NY14853, USA.(mp337@cornell.edu)

\begin{abstract}
N. Kukowski ${ }^{\mathrm{c}}$
${ }^{\mathrm{c}}$ Helmholtz Zentrum Potsdam, Deutsches GeoForschungsZentrum (GFZ),

Telegrafenberg, 14473 Potsdam, Germany. (nina.kukowski@gfz-potsdam.de)
\end{abstract}

\begin{abstract}
A long-standing goal of subduction zone earthquake studies is to determine whether or not there are physical processes that control seismogenesis and the along-strike segmentation of the megathrust. Studies of individual earthquakes and global compilations of earthquakes find favorable comparison between coseismic interplate slip distributions and several different long-lived forearc characteristics, such as bathymetry, coastline morphology, crustal structure, and interplate frictional properties, but no single explanation seems to govern the location and slip distribution
\end{abstract}


of all earthquakes. One possible reason for the lack of a unifying explanation is that the inferred earthquake parameters, most importantly the slip distribution, calculated in some areas were inaccurate, blurring correlation between earthquake and physical parameters. In this paper, we seek to test this possibility by comparing accurate slip distributions constrained by multiple datasets along several segments of a single subduction zone with the various physical properties that have been proposed to control or correlate with seismogenesis. We examine the rupture area and slip distribution of 6 recent and historical large $\left(M_{w}>7\right)$ earthquakes on the Peru-northern Chile subduction zone. This analysis includes a new slip distribution of the 14 November $2007 M_{w} 7.7$ earthquake offshore Tocopilla, Chile constrained by teleseismic body wave and InSAR data. In studying the 6 events, we find that no single mechanism can explain the location or extent of rupture of all earthquakes, but analysis of the forearc gravity field and its gradients shows correlation with many of the observed slip patterns, as suggested by previous studies. Additionally, large scale morphological features including the Nazca Ridge, Arica Bend, Mejillones Peninsula, and transverse crustal fault systems serve as boundaries between distinct earthquake segments.

Key words: subduction zone, radar interferometry, slip distribution, seismic segment, 2007 Tocopilla earthquake

\section{$1 \quad 1$ Introduction}

2 A basic question of subduction zone earthquake phenomenology is whether 3 earthquakes occur randomly along a megathrust or if some physical properties 4 of the forearc and/or the interface itself encourage or discourage repeated 5 rupture of a more-or-less spatially invariant region. This question is important

6 because it has implications for both hazard assessment and understanding 
7 earthquake physics, because if seismicity is not random, key characteristics of 8 large earthquakes (i.e., where they begin, end, and achieve maximum slip) can 9 be forecast through analysis of physical properties.

A key obstacle we face in determining whether or not earthquake locations are random along a fault is limited temporal sampling. We usually only have detailed information about the last one or two earthquakes in a given area, although paleoseismology may offer insight into as many as 10 past events (e.g., Cisternas et al., 2005; Nelson et al., 2006; Natawidjaja et al., 2006), and geological observations may in some cases be capable of placing constraints on longer-term $\left(10^{4}-10^{6}\right.$ years) behavior (Loveless et al., 2009; Melnick et al., 2009). A large number of studies have attempted to use modern, historic, and paleoseismic records to correlate earthquake location and slip with physical properties of the downgoing and overriding plates, or the interface between the two plates (see list and references in Section 3 and Table 1). Although several studies have found correlations for individual earthquakes or sets of events, no single, comprehensive physical property seems to explain all characteristics of every earthquake.

There are at least 4 possible explanations for the lack of a single, global property correlating with earthquake parameters: 1) Multiple physical processes influence the rupture; 2) Even if one property dominates seismic patterns in a given subduction zone, spatial variations of this property may limit its influence over earthquakes elsewhere; 3) The inferred earthquake parameters, most importantly the slip distribution, calculated for some events were inaccurate, blurring any correlation with physical parameters. For example, this could be an explanation for the lack of correlation between geologic structures or morphotectonic provinces with earthquakes in southern Chile from 1570-1960 
found by Rehak et al. (2008), although comparing deformation across multiple time scales is complicated by the wet climate of that region. This is the possibility that we seek to test in this paper by comparing accurate slip distribution constrained by multiple datasets along several segments of a single subduction zone with the various physical properties that have been proposed to control or to be correlated with seismogenesis; 4) We must wait many more centuries to gather enough data to rigorously test correlations between earthquake characteristics and physical properties (e.g., McCaffrey, 2007), and we will consider this possibility in the conclusion.

\section{Study area}

We focus on the South American subduction zone including central-southern Peru and northern Chile (latitudes $12^{\circ}-26^{\circ} \mathrm{S}$ ) because the area has experienced nine $M_{w} 7$ or larger earthquakes between the years 1992-2007 (Figure 1), and several datasets are available to constrain the distribution of coseismic slip on the megathrust. Our analysis starts in 1992, because earthquakes after this date can be constrained by both seismic and geodetic (primarily satellite Interferometric Synthetic Aperture Radar, InSAR) datasets. We have found that InSAR can reveal details of the earthquake slip distribution beyond what is possible with conventional teleseismic body waveforms alone, particularly for large events $\left(M_{w}>7.5\right)$ in subduction zones (e.g., Pritchard et al., 2007).

In this work, we focus on the inferred slip distributions from six of the seven shallow inter-plate earthquakes with $M_{w}>7$. We present new results here for the $M_{w} 7.7$ earthquake near Tocopilla, Chile on 14 November 2007 and use our previously published models for the remaining five of these earthquakes 
(1995 $M_{w} 8.1$ Antofagasta, Chile; $1996 M_{w} 7.7$ Nazca, Peru; $1998 M_{w} 7.1$ Antofagasta, Chile; $2001 M_{w}$ 8.5 Arequipa, Peru; $2007 M_{w}$ 8.1 Pisco, Peru; Pritchard et al., 2006, 2007; Pritchard and Fielding, 2008). For all earthquakes, we use InSAR and teleseismic body waves to estimate the distribution of coseismic slip. The models for some of the earthquakes also consider local strong motion data and GPS displacements. There are other published studies for the earthquakes that occurred before 2007 (e.g., Ruegg et al., 1996; Delouis et al., 1997; Ihmlé and Ruegg, 1997; Swenson and Beck, 1999; Spence et al., 1999; Giovanni et al., 2002; Bilek and Lay, 2002; Salichon et al., 2003), and comparisons of our models with these are available in Pritchard et al. (2006, 2007) and Loveless and Pritchard (2008). We compare our well-constrained slip distributions with those of important historical earthquakes that are less well constrained, including the $1868 M \sim 9$ southern Peru and $1877 M \sim 9$ Iquique, Chile events (e.g., Comte and Pardo, 1991). Our main goal is to find correlations between these slip distributions and various physical properties of this particular subduction zone.

We begin by providing an overview of the physical properties that might control the earthquake process in subduction zones. We next demonstrate our methodology for inferring the slip distributions for the earthquakes by showing new results for the 2007 Tocopilla, Chile event. We then compare the slip distributions with the proposed physical processes to see which, if any, dominate slip distributions within this single subduction zone. Our objective is to determine whether successful forecasts of the earthquake parameters could have been made in advance based on the physical properties of the subduction zone. Achieving this goal would allow us to assess the size and approximate slip distribution of earthquakes that will rupture the seismic gaps remaining 
in the 1868 and 1877 rupture zones.

\section{Overview of proposed explanations for seismic segmentation}

Before beginning our analysis, we define several terms relevant to subduction zone seismogenesis. The up-dip and down-dip limits of coseismic rupture on the megathrust define the boundaries of the seismogenic zone. The seismogenic zone spans 10-40 km depth on average in subduction zones, although there are regional (e.g., Zhang and Schwartz, 1992; Tichelaar and Ruff, 1993; Pacheco et al., 1993) and sub-regional (e.g., Pritchard and Simons, 2006) variations in depth. Because large earthquakes $\left(M_{w}>7.5\right)$ break most of the seismogenic zone, the main control on whether a particular earthquake becomes a $M_{w} 8$ or $M_{w} 9$ event is fundamentally determined by the along-strike extent of rupture, or length of the seismic segment of the megathrust. One useful paradigm for understanding the along-strike rupture length is the asperity and barrier model (e.g., Das and Aki, 1977; Lay and Kanamori, 1981; Scholz, 2002). An asperity is a region of large coseismic slip while a barrier is a region of low to zero slip that inhibits or terminates the rupture. An earthquake segment can be thought of as a single large asperity or a collection of smaller ones. It has been observed that the asperities may rupture together at times and separately at others (e.g., Kanamori and McNally, 1982; Comte et al., 1986; Beck and Ruff, 1989; Kodaira et al., 2006), but the region encompassing the asperities is defined as the maximum possible rupture area. Alternatively, an earthquake segment might be defined by physical barriers that do not allow slip to propagate uninhibited along the entire subduction zone.

A fundamental assumption implicit in the concept of a stable earthquake seg- 
ment is that asperities and barriers are long-term features. Several workers have proposed that seismic segments are correlated with geologic features (see references in Table 1) that would affect seismogenesis for time spans of order $10^{6}$ years or more. Observations of historic re-ruptures of the same region are consistent with long-lived segments (e.g., Igarashi et al., 2003; Yamanaka and Kikuchi, 2004; Okada et al., 2005). On the other hand, several observations and theoretical arguments suggest that the effect of asperities and barriers on seismogenesis may not be constant and depends on the time since the last earthquake and/or the stochastic dynamic properties of previous earthquakes (e.g., Scholz, 2002; Thatcher, 1990; Schwartz, 1999; Satake et al., 2006; Park and Mori, 2007). "Moving" asperities and/or barriers do not necessarily invalidate the idea of long-lived seismic segmentation unless earthquakes consistently cross previously defined segment boundaries. Therefore, we seek to separate processes that might operate at different timescales: 1) the seismogenesis of individual earthquakes $\left(10^{1}-10^{3}\right.$ years) related to asperities and/or barriers that may or may not have a long-lived geologic origin; and 2) integrated effects of several individual earthquakes defining seismic segments ( $>10^{3}$ years), which would most likely have a long-lived geologic origin.

For the sake of clarity, we divide the proposed causes of seismic segmentation (Table 1) into four categories:

- Upper plate structures (particularly crustal faults that may interact with the plate boundary)

- Upper plate structure and morphology (variations in forearc lithology, gravity anomaly field, and coastline shape)

- Lower plate structures (subducting bathymetric features, such as seamounts, ridges, and fracture zones, which may influence coastline morphology and 
the gravity anomaly field)

- Interface properties (frictional properties controlled by characteristics such as thickness of sediment subducted)

\section{New slip model for the 2007 Tocopilla earthquake}

Our detailed slip maps of the recent Andean earthquakes allow insight into several properties of the earthquake rupture, including the along-strike and down-dip extents of slip and the directivity and concentration of slip, and we seek to compare these properties with the various physical characteristics of the seismic segment. We estimate the slip distribution for the six earthquakes by joint inversion of seismic and geodetic data. We illustrate the methodology by presenting a new result: the slip distribution for the 14 November $2007 M_{w}$ 7.7 earthquake near Tocopilla, Chile.

\subsection{Data used}

We use InSAR data from the Envisat satellite of the European Space Agency (with a C-band radar, $5.6 \mathrm{~cm}$ wavelength) and the ALOS satellite (L-band, $23.6 \mathrm{~cm}$ ) from the Japanese Space Agency (JAXA, see Table 2). We use two tracks of Envisat and two tracks of ALOS data including both ascending and descending orbits (Figure 2, Table 2). Information on the data selection and processing is in the Appendix.

We use digital $\mathrm{P}$ and $\mathrm{SH}$ teleseismic displacement records (between $30^{\circ}$ and $90^{\circ}$ ) from the digital global network (Butler et al., 2004) and select a subset of stations that are azimuthally well distributed (Figure 3). See Pritchard et al. 
(2006) for more details about selection and processing of the teleseismic data. We use $18 \mathrm{P}$ and $11 \mathrm{SH}$ waveforms extending 90 seconds after the arrival of each phase.

\subsection{Methodology}

We use the method of Ji et al. (2002) to invert for fault slip using the seismic and InSAR data both separately and together. The seismic data are transformed into the wavelet domain to better utilize the temporal and frequency content of the waveforms while solving for the rupture properties. The forward model is generated by a combination of point-source dislocations to create subfaults with a specified fault geometry. Calculations are performed in an elastic layered medium using a velocity model generated by a combined onshore/off-shore seismic network using aftershocks from the nearby 1995 Chile earthquake (Husen et al., 1999). When calculating the InSAR forward models, we account for the variations in the incidence angle across the radar scene.

One uncertainty in modeling is the location of the hypocenter, which differs by 10's of km (Figure 4) between the solutions from the USGS (which uses teleseismic data) and Departamento de Geofisica (DGF) at the Universidad de Chile (which uses local data). We use the DGF hypocenter (but also show the USGS hypocenter in the Figure 4). We use a single fault plane with a dip of $23^{\circ}$ and strike of $5^{\circ}$, which are similar to the parameters of the Global CMT mechanism $\left(20^{\circ}\right.$ dip and $358^{\circ}$ strike) and consistent with the values used for the 1995 Antofagasta earthquake, which occurred immediately to the south of the 2007 event (Pritchard et al., 2006). 
We perform non-linear inversions using simulated annealing, which searches through bounded regions of parameter space to find models that best match the data in a least-squares sense. See Table 3 for the range of parameters used. In addition to finding a model that well fits the data, we also seek to minimize the roughness of the slip distribution using a Laplacian operator and for some inversions we also minimize the difference between the calculated seismic moment and an a priori value. Additional details on the methodology are available in the Appendix.

\subsection{Results}

The slip distributions from the teleseismic-only, geodetic-only and joint inversions for the 2007 earthquake are shown in Figure 4. Key parameters of the slip distribution are shown in Table 3 . The fit to the seismic data is not significantly different between the seismic-only and the joint inversion (Figure 3). The fit to the interferograms is shown in Figure 5 and is not significantly degraded between the InSAR only and joint inversions. Like other earthquakes in the area, most of the slip occurred south of the hypocenter as defined by both the DGF and USGS solutions, reaching a maximum of about $3 \mathrm{~m}$ just east of the north end of the Mejillones Peninsula (the peninsula is labelled in Figure 1).

We show the published slip distributions (Pritchard et al., 2006, 2007; Pritchard and Fielding, 2008) for the Tocopilla and other earthquakes overlain on the forearc gravity fields of central-southern Peru and northern Chile in Figures 6 and 7 . 


\section{Discussion}

In the sections that follow we review in turn the various physical properties that have been proposed to explain segmentation and seismogenesis (Table 1) and summarize the evidence suggesting that these properties are important. At the end of each section, we critically examine how each physical property may influence our derived slip maps for the southern Peru and northern Chile subduction zone earthquakes. We focus primarily on the five earthquakes that ruptured unique segments of the plate boundary; the $1998 M_{w} 7.1$ event near Antofagasta may represent a large aftershock of the 1995 earthquake, but we note some correlation between this smaller event and forearc traits.

\subsection{Do large-scale plate tectonic processes control seismogenesis?}

Great shallow thrust earthquakes $\left(M_{w}>8\right)$ do not occur in all subduction zones (Kanamori, 1986). The best explanations for differences in seismic behavior between subduction zones so far seem to be plate-scale variations in temperature, plate age, convergence rate, dip angle, strength of the upper plate, and/or normal tractions on the plate interface (e.g., Kanamori, 1986; McCaffrey, 1993; Scholz and Campos, 1995; McCaffrey, 1997), although McCaffrey (2007) argues that the large-scale differences are not well understood and observed variations in seismicity could be an artifact of incomplete temporal sampling. Observations along the Andean margin and other subduction zones indicate that smaller scale variations in frictional properties on the plate interface are of equal or greater importance than these plate-scale variations (e.g., Pacheco et al., 1993; Song and Simons, 2003; Wells et al., 2003; Miyazaki 
et al., 2004; Pritchard and Simons, 2006). For example, the plate age and rate of convergence are similar in southern Peru and northern Chile (Müller et al., 1997; Angermann et al., 1999). Thus, the variations in earthquake parameters that we see cannot be explained with a simple interpretation in terms of variations in temperature with depth or broad scale changes in normal tractions on the fault interface, and instead must result from smaller-scale fluctuations.

\subsection{Correlation between slip and bathymetric features}

Unlike along transform faults or normal faults, in a subduction zone setting, we can physically image one side of a fault before it makes contact with the other side to understand the initial condition. That is, by using bathymetric and seismic data, we can examine the properties of the subducting oceanic plate seaward of the trench and infer how these features may influence seismic processes once they become active parts of the plate interface. Several studies have highlighted the effects of seafloor roughness (e.g., Cloos, 1992; Bilek et al., 2003; Robinson et al., 2006), temperature (Newman et al., 2002), or seamounts on seismogenesis (e.g., Kodaira et al., 2000; Abercrombie et al., 2001), which can serve to physically segment or impede the rupture process (Kelleher and McCann, 1976; Ramírez-Herrera and Urritia-Fucugauchi, 1999; Kodaira et al., 2000; Robinson et al., 2006), or concentrate slip as asperities (e.g., Abercrombie et al., 2001).

The Nazca Plate is generally characterized by considerable seafloor ruggedness. However, morphological styles and orientations of linear features vary substantially seaward of the central Andean trench. Off northern and central

Peru, bathymetric structures are oblique to the trench (Kukowski et al., 2008), 
off southern Peru and northern Chile they are largely parallel to the trench (Kukowski et al., 2008; von Huene and Ranero, 2003), and off Valparaiso, trench-parallel structures on the Nazca plate are cut by features striking perpendicular to them (Laursen et al., 2002). Normal faults related to bending of the slab as it enters the subduction trench are absent between 9 and $11^{\circ} \mathrm{S}$ but are seen along all other sections of the central Andean trench where swath bathymetry allows for their identification (e.g., Hagen and Moberly, 1994; Kukowski et al., 2008; von Huene and Ranero, 2003; Laursen et al., 2002). Off Peru, bathymetric relief generally decreases from north to south (Kukowski et al., 2008). Off northern Chile, relief is similar to that off central Peru, but bathymetric highs and lows are more widely spaced (von Huene et al., 1999). Compared to the surrounding seafloor, the Nazca Ridge, an elongated basement high of thickened oceanic crust obliquely colliding with the south Peruvian trench, has a smoother surface (Hampel et al., 2004). This contrasts with the Iquique Ridge (Figure 1) and the Juan Fernandez Ridge (located outside the study area at $33^{\circ} \mathrm{S}$ ), which consist of chains of individual seamounts, some of which are presently being subducted (e.g., Laursen et al., 2002).

The boundary between the 1996 Nazca and 2007 Pisco, Peru earthquakes coincides with subduction of the Nazca Ridge (Figures 1,6) and represents a region that has not slipped since at least 1746 and possibly 1687 (Beck and Nishenko, 1990). The slip deficit apparently cannot be filled with rapid afterslip (Pritchard and Fielding, 2008). While the slip deficit may be filled in future earthquakes, it is also possible that the subduction of the Nazca Ridge is at least partly aseismic (e.g., Dorbath et al., 1990, although Okal et al. (2006) give an opposing view). Spence et al. (1999) speculate that, as the Nazca Ridge migrates to the southeast, its leading edge is more strongly 
coupled to the upper plate than is the trailing edge. However, the 2006/2007 Pisco earthquake sequence occurred at the trailing edge. The low rupture velocity of the 2007 event may indicate a physical change in the properties of the megathrust associated with ridge subduction or different initial stress conditions on the fault plane (Pritchard and Fielding, 2008).

Robinson et al. (2006) suggested that the subduction of the Nazca Fracture Zone (NFZ, Figures 1,6) dictated the spatiotemporal evolution of slip during the 2001 Arequipa earthquake. They constrained the pattern of coseismic slip using inversion of teleseismic SH waves and found two time intervals during which rupture encircled barriers to slip on the interface. They correlated the larger barrier with the subducting NFZ, which introduces several hundred meters of relief on the ocean floor, and the smaller barrier with a subducting seamount. The slip distribution of Robinson et al. (2006) is quite different from the solutions presented by Pritchard et al. (2007) for the 2001 earthquake: Robinson et al. (2006) found the maximum slip occurring very near the hypocenter at the northwest edge of the rupture area, while the Pritchard et al. (2007) solutions show slip concentrated in the southern $1 / 2-2 / 3$ of the fault, regardless of the constraining data used. The along-strike continuity of the NFZ beneath the overriding plate approximately marks the northwestern extent of substantial slip as presented by Pritchard et al. (2007), suggesting that it may represent a seismic segment boundary. As is the case with the Nazca Ridge to the north, the NFZ propagates southward through time relative to South America due to the azimuth of plate convergence, suggesting that any influence it exerts on seismicity is transient, at least on geological timescales.

The Antofagasta Ridge, identified by von Huene and Ranero (2003) as a sub- 
merged feature lying south of and similar in size and morphology to the Mejillones Peninsula, as well as an additional ridge north of the peninsula, may have impacted the rupture process of the 1995 and 2007 Tocopilla earthquakes, respectively. The Antofagasta Ridge is difficult to see in the low resolution bathymetry of Figure 7, but the bathymetric highs north and south of the Mejillones Peninsula are reflected in the positive gravity anomalies trending parallel to the trench on either side of the peninsula in Figure 7. The majority of slip in both the Tocopilla and Antofagasta earthquakes occurred downdip of these ridges. Both ridges and the Mejillones Peninsula are interpreted by von Huene and Ranero (2003) as blocks tilted seaward due to "bookshelf" style normal faulting, with the peninsula being the only block that emerges above sea level. The blocks trend parallel, not perpendicular, to the margin, indicating that they may not be long-lived subducted features like the Nazca Ridge. As prominent upper plate features, their presence and interaction with the subduction interface may influence the style of interplate slip. We return to this point in our discussion of the forearc gravity field.

\subsection{Correlation between slip and over-riding plate geologic faults}

In addition to discrete structures on the lower plate, crustal faults in the overriding plate that strike orthogonal to the trench may be important in defining earthquake segment boundaries. These faults may juxtapose lithologically different upper plate materials, "absorb" some of the earthquake slip from the megathrust, and/or serve as an obstruction to plate boundary slip propagation due to the fractured, low rigidity nature of the crustal fault zone. Upper plate faults in Colombia that strike nearly perpendicular to the trench are 
correlated with the segmentation seen in the 1942, 1958, and 1979 earthquake sequence that, when summed together, ruptured the equivalent length, but not magnitude (Kanamori and McNally, 1982), of the great 1906 event (e.g., Collot et al., 2004). In addition, the southeast termination of the 2001 Peru earthquake is aligned with the onshore northeast striking Chololo Fault System (Figure 6 Audin et al., 2008). The boundary between the 1877/2007 and 1995 earthquakes in northern Chile coincides with the Mejillones Peninsula, the northern and southern edges of which are marked by submarine transverse fault zones (von Huene and Ranero, 2003). These faults are quite subtle, however, and lack the onshore surface expression (Niemeyer et al., 1996; Delouis et al., 1998) of the more prominent Columbian and Peruvian faults, suggesting that additional mechanisms might contribute to the role of the peninsula as a segment boundary.

The 2001 Arequipa earthquake broke the northwestern $\sim 2 / 3$ of the inferred 1604 and 1868 rupture area (Dorbath et al., 1990; Comte and Pardo, 1991), prompting Giovanni et al. (2002) to suggest that the southernmost Peru segment of the margin experiences two styles of rupture: truly great $\left(M_{w} \sim 9\right)$ earthquakes, such as those of 1604 and 1868, and great but slightly smaller 2001-type events (up to $M_{w} 8.5$ ). Giovanni et al. (2002) propose that the rupture area for an event in 1784 was similar to that of the 2001 earthquake. Furthermore, two events - a $M_{w} 8.0$ in 1687 and a $M_{w} 7.5$ in 1715 (Dorbath et al., 1990; Comte and Pardo, 1991) - together may have broken the 1604/1868 segment, while a $M_{w}$ 7.2-7.7 1833 Peru-Chile border earthquake (Dorbath et al., 1990) may represent the complement to the 1784 earthquake. The 1687 rupture area, according to Comte and Pardo (1991), is similar to that of the 2001 event and slightly smaller than that which broke in 1784, suggesting 
that the 2001 earthquake repeated the 1687/1784 event and a 1715/1833-type event, which may rupture the yet-unbroken portion of the 1868 segment, could strike in the next few decades.

The assessment of Giovanni et al. (2002) that segments may break in two different styles could depend on the interaction between physical characteristics influencing the rupture limits. If the Chololo Fault System is capable of acting as a barrier to interplate rupture by accommodating some earthquake slip, then the rupture style of a great earthquake in southern Peru is dictated not only by the factors governing recurrence of slip on the megathrust, but also on upper plate structures. If the state of stress on the Chololo Fault System were not suitable for triggered failure during the 1604 and 1868 earthquakes, megathrust slip could propagate through the Ilo region. Conversely, if in 1687 and 2001 slip was triggered on upper plate faults, as some shallow aftershocks suggest (Audin et al., 2008), megathrust rupture may have been impeded, resulting in a smaller earthquake and leaving the southeastern extent of the seismic segment unbroken but ripe for future failure. This bimodal nature of seismicity is similar to the style proposed for the Nankai trough in Japan, in which a patch of the subduction interface alternates between serving as a barrier to rupture, resulting in a coupled pair of earthquakes, and allowing continuous rupture along a $600 \mathrm{~km}$ long segment of the margin (Kodaira et al., 2006).

In northernmost Chile between $19.25^{\circ}$ and $21.5^{\circ} \mathrm{S}$ are a series of east-west striking reverse faults that accommodate shortening perpendicular to the plate convergence direction (Figure 1; Allmendinger et al., 2005a; Carrizo et al., 2008). Such faults may be correlated with intraplate earthquakes, such as the $M_{w} 5.7$ event that occurred near the town of Pisagua at $28 \mathrm{~km}$ depth on 24 
March 2007, and could also serve to segment the Iquique segment of the plate boundary. The northern end of the 2007 Tocopilla earthquake is about 50 $\mathrm{km}$ south of the southernmost major reverse fault described by Allmendinger et al. (2005a), located near the Río Loa. Although we are unaware of field evidence indicating surface rupture in that area and no teleseismically recorded aftershocks with focal mechanisms consistent with that style of faulting were observed, there remains the possibility that these faults may interact with the subduction interface, similar to the interpreted behavior of the Chololo Fault System near Ilo (Figure 1; Audin et al., 2008). Even if no crustal fault was activated by the Tocopilla event, the near coincidence of the rupture termination with the Río Loa faults may suggest previous partitioning between interplate and crustal fault slip on the Iquique segment.

While much of the seismogenic zone ruptures during great earthquakes, it is possible that the down-dip limit of interplate rupture could be affected by slip on faults striking parallel to the margin. The examples of earthquake segmentation in Colombia (Collot et al., 2004) and Peru (Audin et al., 2008) involve faults striking nearly perpendicular to the plate boundary. During the 2007 Pisco earthquake, $\sim 0.5 \mathrm{~m}$ of vertical throw on a margin-parallel reverse fault was observed (Audin et al., 2007), while $\sim 0.2-0.3 \mathrm{~m}$ of normal displacement was reported following the 1995 Antofagasta earthquake on the north-south striking Atacama Fault System (Delouis et al., 1998; Klotz et al., 1999). Outside of our study area in the Arauco-Concepción, Chile area, the morphology of near-coast islands indicates that margin-parallel crustal reverse faults may be activated during megathrust earthquakes (Melnick et al., 2006). If these examples of minor near-surface deformation reflect partitioning of earthquake slip between the plate interface and margin-parallel crustal structures, it may 
be the case that upper plate faults are capable of accommodating some slip that otherwise would occur on the plate interface. Such a phenomenon may explain the anomalously shallow down-dip extent of rupture of the Antofagasta earthquake (Pritchard et al., 2006) if significant slip were released on the upper-plate Atacama Fault System.

\subsection{Correlation between slip and long-term tectonic uplift and topography}

There is not necessarily any a priori reason to expect that earthquake slip and the vertical deformation it induces should be correlated with long-term tectonic uplift or topography. In fact, the classic subduction zone earthquake cycle of Savage (1983) assumes that there is no net deformation of the surface during the cycle. While Savage (1983) cites some observations that support the idea of little net deformation, the Andean margin shows several pieces of evidence for long-term uplift, including the Mejillones Peninsula, Chile (Delouis et al., 1998; González et al., 2006, and references therein) and near Nazca, Peru (Hsu, 1992; Machare and Ortlieb, 1992). Even if the topography and surface uplift are not directly caused by slip on the subduction megathrust, they may be related to motion on upper crustal faults that are impacted by megathrust slip.

We compare the coseismic vertical displacements from our earthquake analyses with topography to test for any direct correspondence between short and longterm deformation (Figures 8, 9, 10). Again, there is not any reason to expect that deformation in a single earthquake should be related to the net surface deformation over many seismic cycles, but a direct correspondence has been proposed near Nazca, Peru related to the 1996 earthquake (Swenson and Beck, 
1999; Spence et al., 1999; Salichon et al., 2003), and we seek to test this idea for the studied earthquakes.

It is worth noting that the accuracy of all of our coseismic vertical deformation maps are not the same. InSAR only measures deformation in the radar line-of-sight (LOS, about $23^{\circ}$ off nadir for the data used in the solutions presented here), and multiple tracks of InSAR (especially including descending and ascending orbits) are needed to separate out the vertical and horizontal components. The quantity and quality of InSAR data vary for each earthquake, but all of the earthquakes were studied with multiple tracks of InSAR data and all but the 1998 Chile earthquake had both ascending and descending tracks. The Appendix includes further discussion of the accuracy of our vertical deformation maps.

In Figure 10 we compare the coseismic vertical deformation predicted by our slip distributions with the topography of each study area. The values shown in Figure 10 were extracted from swath profiles through a global 1-minute resolution model of topography and bathymetry (Sandwell and Smith, 1997) and the composite uplift fields from the six studied earthquakes. We present the mean elevation and vertical displacement data from a series of seven parallel profiles spaced $\sim 10 \mathrm{~km}$ apart and centered on the white line in Figures 8 and 9. Therefore, the mean elevation samples both on and offshore coastal regions, while the vertical displacement profile represents the mean of onshore data only. We find that topography and uplift are correlated along some lengths of the profile but for the most part are un- to anti-correlated. For example, the maximum mean elevation near the Nazca-Arequipa segment boundary coincides with a zone of coseismic uplift (Figure 10). This region also represents a local drainage divide, with channels to the north of the uplifted zone 
showing plan-view curvature towards the northwest, and those to the south showing southeast curvature (Figure 8). Immediately northwest throughout the Nazca segment, coseismic uplift is high, while mean elevation is relatively low $(\sim 200 \mathrm{~m})$.

As previous workers have noted (Spence et al., 1999; Swenson and Beck, 1999; Salichon et al., 2003), coseismic surface uplift from the 1996 earthquake is correlated with local topography and marine terraces that have been uplifted since the late Pliocene. The location of maximum on-shore coseismic uplift $(\sim 35 \mathrm{~cm})$ is nearly coincident with that of long-term uplift (Swenson and Beck, 1999). Comparing the observed uplift magnitude $(35 \mathrm{~cm})$ with rates of long-term uplift (0.3-0.7 mm/yr (Hsu, 1992)) implies an recurrence interval of 500-1000 years; this is unrealistically long for this area, given that the previous rupture of the 1996 earthquake area was apparently similar in 1942 (Spence et al., 1999; Swenson and Beck, 1999; Salichon et al., 2003). So although there is an interesting correlation between the coseismic and long-term uplift patterns, it is clear (and not surprising) that the coseismic deformation is not the complete picture and might, in fact, be a coincidence. The imbalance between short- and long-term vertical deformation rates suggests that coseismic uplift must be partially offset by interseismic or postseismic subsidence.

In Chile, due to the deeper and more landward locus of slip during the 2007 Tocopilla earthquake, coseismic uplift characterizes much of that segment, as opposed to the prevalence of subsidence related to the shallower Antofagasta earthquake (Figures 9,10), except on the southwestern edge of the Mejillones Peninsula. The combined deformation from the 1995, 1998 and 2007 northern Chile earthquakes and postseismic deformation from 1995-2000 produces net uplift across the Mejillones Peninsula of about $50 \mathrm{~cm}$ in the south and $30 \mathrm{~cm}$ 
in the north. The pattern of uplift is opposite that averaged over the last $10^{3}$ $10^{5}$ years, which shows uplift of the north half of the peninsula and less uplift, stability or subsidence at the southern end (Delouis et al., 1998; González et al., 2006; Victor et al., 2006, and references therein). Some estimates of uplift rates based on dating of marine terraces indicate that coseismic uplift of the peninsula due to 1995-type earthquakes must be partially offset by interseismic and/or postseismic subsidence. Given the observed uplift (order $10 \mathrm{~cm})$ and rates of long-term uplift $(0.1-0.25 \mathrm{~mm} / \mathrm{yr}$, Ortlieb et al., 1996b; González et al., 2006, and references therein), the implied earthquake recurrence interval is 400-1000 years, which, as is the case for the 1996 Nazca region, is much longer than estimated by historical records (Comte and Pardo, 1991). Other, faster estimates of peninsula uplift rates $(0.5-0.6 \mathrm{~mm} / \mathrm{yr}$, Casanova et al., 2006a,b) suggest that coseismic displacement could explain a higher proportion of uplift, as the predicted recurrence interval is a more reasonable $\sim 170-200$ years.

\subsection{Correlation between slip and coastline location}

Ruff and Tichelaar (1996) observed that the landward limit of rupture in subduction zone megathrust earthquakes is often correlated with the coastline. The location of the coastline is roughly related to where the Moho intersects the subducting plate (Ruff and Tichelaar, 1996), and so this material interface might effect the downdip seismic limit (Tichelaar and Ruff, 1991). In northern Chile, near the coast, the Moho is between 40-50 km depth (Wigger et al., 1994), but the exact location of the intersection of the Moho with the subducting plate is not known. In other subduction zones (e.g., Cascadia and 
Nankai), temperature seems to control the downdip limit $\left(350-450^{\circ} \mathrm{C}\right)$, but at the northern Chile subduction zone these temperatures are not reached until $70 \mathrm{~km}$ depth due to the old age of the Nazca Plate and the lack of insulating sediments blanketing the interface (Oleskevich et al., 1999). The landward limit of the 1995, 2001, and 2007 Pisco, Peru earthquakes is near the coastline, but the 1996 Nazca, 1998 Antofagasta, and 2007 Tocopilla earthquakes clearly ruptured landward of the coastline.

Seismic studies used to estimate Moho depth have either concentrated on a single profile from the trench across the Andean orogen (e.g., ANCORP Working Group, 1999; Masson et al., 2000) or estimated crustal thickness in a broad region at relatively low resolution (e.g., Yuan et al., 2002; McGlashan et al., 2008). Thus, while along-strike changes in Moho depth may be important in serving to segment the plate boundary, we are unable to accurately track such variation and therefore make conclusive statements about their role in seismic segmentation.

\subsection{Correlation between slip and coastline morphology}

Coastline morphology may also provide insight into the along strike patterns of earthquake rupture. On a global scale, peninsulas appear to serve as markers of seismic segment boundaries. For example, Montero (1986) defines four seismic segments along the well-studied Costa Rican margin, with boundaries between adjacent segments coinciding with the Nicoya, Osa, and Burica Peninsulas. Other global examples of seismic segmentation marked by peninsulas are the Kii Peninsula in southwest Japan, which Kodaira et al. (2006) suggest served as the boundary between the 1944 and 1946 earthquakes, and 
along the scalloped coastline of the Kamchatka Peninsula, where locations of historical earthquakes (Song and Simons, 2003; Wells et al., 2003) and strong interseismic coupling (Bürgmann et al., 2005) show anti-correlation with small peninsulas.

There are several peninsulas within our study area, but only the Mejillones Peninsula of northern Chile is an obvious candidate for a segment boundary. The Ilo Peninsula of southern Peru is located at the southeast end of the 2001 rupture (Figure 1) but, as mentioned above, rupture may have terminated at this locality due to interactions with the Chololo Fault System (Audin et al., 2008). The Paracas Peninsula (Figure 1), which overlies the 2007 Pisco earthquake, is small and has no discernible effect upon the slip distribution. The Mejillones Peninsula in northern Chile, however, has long been suspected to mark a segment boundary because the 1877 earthquake may have terminated there, the 1995 Antofagasta earthquake clearly nucleated there (e.g., Ruegg et al., 1996; Delouis et al., 1997), and the 2007 Tocopilla earthquake terminated there (Figure 4). In addition, Pritchard and Simons (2006) found that the afterslip following the 1995 event was primarily located $\sim 100 \mathrm{~km}$ north of the main 1995 asperity at the northern edge of the Mejillones Peninsula (Figure 11), and that no large aftershocks $\left(M_{w}>6.5\right)$ had nucleated under the peninsula. In fact, the rate of fault slip $(\sim 10 \mathrm{~cm} / \mathrm{yr})$ beneath the peninsula between 1995-2000 is nearly twice the plate convergence rate ( $\sim 6 \mathrm{~cm} / \mathrm{yr})$, suggesting that perhaps the subduction interface beneath the Mejillones Peninsula does not accumulate as much stress as surrounding regions because of different material properties (Song and Simons, 2003; Pritchard and Simons, 2006). The 2007 Tocopilla earthquake is consistent with this scenario because, while it did include some slip beneath the peninsula itself, a composite slip 
map still shows a cumulative slip deficit beneath the peninsula (Figure 11). The rapid aseismic afterslip following the 1995 Antofagasta earthquake may represent a short-term pulse of deformation capable of triggering seismic events beneath the peninsula (Pritchard and Simons, 2006). The Tocopilla rupture, however, initiated about $100 \mathrm{~km}$ north of the peninsula and propagated southward towards the region of maximum slip, indicating that, if the earthquake was indeed triggered by the Mejillones slip pulse, there is a complicated relationship between aseismic triggering and the origin of rupture.

The substantial bend in the coastline (Arica Bend, Figure 1) and subducting slab at the Peru-Chile border defines the first-order morphology of the Andes (e.g., Isacks, 1988; Gephart, 1994) and exerts influence over short- and long-term patterns of deformation throughout the orogen (Bevis et al., 2001; Allmendinger et al., 2005a,b). The bend also appears to mark the boundary between great earthquakes on the northernmost Chile and southernmost Peru segments of the margin (Figure 1, e.g., Comte and Pardo, 1991). Aki (1979) proposed that even subtle changes in the strike of plate boundary faults may serve as "geometric barriers" to earthquake rupture. Kelleher (1972) and Kanamori and McNally (1982) noted that the great $1906 M_{w} 8.8$ earthquake near the Ecuador-Columbia border outside of our immediate study area, ruptured a 500 km segment of the plate boundary between the subducting Carnegie Ridge and a bend in the coastline around $4^{\circ} \mathrm{N}$, indicating that the Arica Bend is not the only deflection along the Andean margin that could serve as a seismic segment boundary. 


\subsection{Correlation between slip and sediments in the trench}

Some of the largest earthquakes have ruptured areas of the megathrust interface covered with significant subducted sediment (Ruff, 1989). Sediments may "smooth out" fault irregularities, encouraging seismic slip over broader areas by allowing small earthquakes to combine into great earthquakes (Ruff, 1989). In the absence of material flux from the continent and sediment atop the incoming Nazca Plate, trench fill along the central Andean margin is very thin (100-400 m) or even close to absent (e.g., Hoffmann-Rothe et al., 2006; Krabbenhöft et al., 2004). Hence, only a small accretionary wedge - nowhere wider than $\sim 12$ to $15 \mathrm{~km}$ - exists between the trench and Paleozoic continental basement of the forearc (e.g. Hampel et al., 2004; Krabbenhöft et al., 2004; Sick et al., 2006; von Huene and Ranero, 2003). Off northern Chile, this wedge may resemble more a "margin wedge" (as defined by Ranero and von Huene, 2000; Sick et al., 2006), whereas off Peru, the geometry seen in seismic reflection data is more typical of an accretionary prism. Past estimates of sediment thickness in the Peru-Chile trench indicate more sediment is subducted in southern Peru than in northern Chile (Figure 1, Schweller et al. (1981)). The increase in the maximum depth of seismicity due to subducted sediments (Zhang and Schwartz, 1992) might explain why the 1996 and 2001 earthquakes in southern Peru ruptured to a greater depth than the 1995 earthquake in northern Chile (Pritchard et al., 2002, 2007). Beyond this possible change in the depth of coseismic slip, along-strike variations in trench sediment do not seem correlated with seismogenesis or seismic segmentation. However, several along-strike variations in the magnitude of afterslip may be related to differences in sediment thickness (Pritchard and Simons, 2006). 


\subsection{Correlation between slip, gravity, and gravity gradients}

Two research groups have proposed that repeated large earthquakes cause negative trench parallel gravity anomalies (TPGA), while positive TPGA are associated with less seismic slip (Song and Simons, 2003; Wells et al., 2003). Llenos and McGuire (2007) found through comparison of recent large earthquakes and TPGA that the relative, rather than absolute, values of TPGA seem to control earthquake rupture patterns. They suggested that maximum coseismic moment release tends to occur in local TPGA minima, with slip decreasing along positive gravity gradients. Similar correlations between alongstrike changes in coseismic slip have been observed offshore Hokkaido, Japan (Wells et al., 2007). However, the great 2005 Nias earthquake ruptured a gravity high, which may indicate that positive gravity anomalies may represent asperities that accumulate strain for very long periods of time and rupture in truly massive events (Wells et al., 2007).

The Peruvian earthquakes show differing levels of agreement with the previously noted TPGA relationships. The 2001 event in southern Peru occurred in a region of dominantly negative TPGA, as expected by Song and Simons (2003); Wells et al. (2003). The near-trench locus of maximum slip in 2001 coincides with slightly less negative TPGA, but this area is poorly resolved by the seismic and geodetic data. In fact, the maximum slip coincides with a local maximum in TPGA, with slip decreasing along negative TPGA gradients (Figure 12). The boundary between the 2001 and 1996 rupture areas coincides with a distinct jump in TPGA from negative to the southeast (2001 rupture area) to positive towards the northwest (1996 rupture area, see Figure 6). The 1996 Nazca and 2007 Pisco events occurred near the the Nazca Ridge which is 
migrating to the southeast (e.g., Hampel, 2002) and so the positive TPGA in this area may not be a steady state feature. Slip during the 2007 Pisco earthquake initiated in a region of weakly negative TPGA but propagated updip to the south along a positive gravity gradient, reaching a maximum near a local minimum in TPGA and falling off abruptly along a steep positive gravity gradient (Figure 12), consistent with the relation noted by Llenos and McGuire (2007). The 1996 earthquake shows an opposite relationship with TPGA to that previously proposed (Song and Simons, 2003; Wells et al., 2003; Llenos and McGuire, 2007), with slip increasing along a positive gradient in TPGA, albeit reaching peak slip in a local TPGA minimum.

In northern Chile, the details of 1995 rupture are correlated with TPGA, with the concentrated region of high-magnitude slip coinciding with negative TPGA that lies between gravity highs (Figures 7, 12). However, Sobiesiak et al. (2007) propose a different interpretation for the relationships between coseismic slip and gravity observations. They suggest that the 1995 asperities are correlated with a high isostatic residual anomaly (IRA, Schmidt and Götze, 2006), which could reflect dense crustal bodies that exert anomalously high normal stress on the interface, enhancing coupling and therefore coseismic slip. While calculations of TPGA and IRA involve different manipulations of the raw gravity observations, the interpretation of the gravity highs (and lows) is the same - corresponding to mass excesses (or deficiencies) - and the spatial patterns of the TPGA and IRA are similar (Figures 7 and 13). Furthermore, both TPGA and IRA are calculated using the Sandwell and Smith (1997) satellite-based gravity database over water, although the IRA derivation uses additional surface-based observations, making its values over land more accurate than those of the TPGA map. 
Therefore, the disagreement between our interpretation that the 1995 peak slip occurred in a gravity low and the Sobiesiak et al. (2007) interpretation that it occurred in a gravity high is based not on the difference between TPGA and IRA, but rather on different inferences of where the 1995 earthquake occurred. Sobiesiak et al. (2007) defines the two 1995 asperities as occurring in areas of high aftershock b-values directly beneath the coastline, while our preferred model (Pritchard et al., 2006, shown in Figures 7, 12), along with other models that use geodetic data (e.g., Ihmlé and Ruegg, 1997; Klotz et al., 1999), have the asperities located farther off-shore. While we think that the maxima of 1995 coseismic slip are better correlated with negative TPGA than positive IRA, the IRA high located at the coastline might explain the anomalously shallow depth of termination of the 1995 earthquake (Figure 13). This termination would be consistent with the suggestion of Wells et al. (2007) that steep gravity gradients, thickened crust, and corresponding high temperatures may overlie the downdip extent of the stick-slip portion of the plate interface. The $M_{w} 7.1$ earthquake in 1998 occurred immediately downdip of the 1995 earthquake and zone of high IRA; it along with several other $M_{w} 6.7-7.5$ events since 1987 appear to have collectively encircled the 1995 rupture zone (Figures 7,13), suggesting that slip during great earthquakes in the area south of Antofagasta may be restricted to above $\sim 35 \mathrm{~km}$, while strain accumulated below this depth may be released by smaller magnitude events.

Because the 2007 Tocopilla earthquake ruptured primarily under land, we can calculate TPGA for only a portion of the rupture because the gravity database used (Sandwell and Smith, 1997) only covers marine areas. It seems that the 2007 earthquake ruptured a weakly positive TPGA region that lies downdip of a strongly positive zone (Figure 7). One unusual characteristic 
of the 2007 earthquake is that it did not rupture as far seaward (up-dip) as the 1995 earthquake. One possible explanation for this might be the positive TPGA up-dip of rupture, if areas of high TPGA correspond to significant aseismic slip as proposed by Song and Simons (2003). Considering the IRA of Schmidt and Götze (2006) we note that while the northern $\sim 2 / 3$ of the Tocopilla rupture zone coincide with a zone of high IRA, the maximum slip occurred at the southern end of the rupture area in a region of only moderate IRA (Figure 13).

Geologic observations suggest that large earthquakes in the area of the 1877 earthquake may rupture primarily in the northern $2 / 3$ of the Iquique segment. Pervasive meter-scale cracks in coastal regions appear to permanently record the deformation induced by large earthquakes. An inversion of the principal coseismic stress orientations, reflected in the strikes of these cracks, for slip on the megathrust suggests a slip concentration between $\sim 18^{\circ}$ and $22^{\circ} \mathrm{S}$, with minor slip occurring near the trench between $\sim 22^{\circ}$ and $23^{\circ} \mathrm{S}$, consistent with the extent of negative TPGA in northernmost Chile (Loveless et al., 2009). The 2007 Tocopilla earthquake ruptured between this inferred 1877 break and the Mejillones Peninsula (Loveless et al., 2009).

\subsection{Correlation between slip and other upper plate traits}

In addition to the noted correlation between the gravity field and great earthquake slip, Tassara et al. (2007) also suggest that the elastic thickness structure of the upper plate is another proxy for crustal structure that appears capable of determining the location of seismic segments (see also Tassara et al., this issue). Even though elastic thickness variations are most evident in 
the inner forearc to Altiplano-Puna plateau regions, along the subduction zone they appear to suggest that the integrated elastic strength of the coupled slaboverriding plate system may exert influence on seismic processes and therefore could be used as a predictive tool in mapping seismic segments.

Upper plate lithology may play a role in seismic segmentation. As suggested by Sobiesiak et al. (2007), dense intrusive bodies may exert anomalous normal stress on the plate interface and serve as asperities during strong subduction zone earthquakes. While there are certainly lithologic variations along the forearc that may influence earthquake rupture patterns, for the most part the composition of the northern Chile and southern Peru forearcs are similar, with Cretaceous-Tertiary volcanics dominating the western slope of the Andes in northern Chile and most of the outer forearc in southern Peru, Tertiary sedimentary rocks within the central depression of northern Chile and along the coast of southern Peru, and Mesozoic arc intrusives and volcanics throughout the Coastal Cordillera of northern Chile and presumably continuing offshore into southern Peru (Schenk et al., 1998). Brudzinski and Allen (2007) showed that the gravity field, off-shore basins (Wells et al., 2003), and composition of the upper-plate along the Cascadia margin explain the segmented nature of episodic tremor and slip (ETS), suggesting that local lithologic variations could serve as long-standing segment boundaries for a range of subduction zone slip phenomena. 


\section{Conclusions}

\subsection{Earthquake summary}

We summarize from north to south our findings for each of the six earthquakes studied (see also Table 4):

The $2007 M_{w}$ 8.0 Pisco, Peru earthquake rupture terminated near the wide collision zone between the Nazca Ridge and South America. The earthquake originated near the northern end of the rupture area, propagated southward to a maximum near the center of the rupture area in a region of moderate TPGA, and slip decreased abruptly as TPGA sharply increased (Figure 12), consistent with the relationship noted by Llenos and McGuire (2007). The rupture was almost completely offshore which required the slip to move updip as the coastline trends seaward around $13.5^{\circ} \mathrm{S}$. The rupture does not seem to have been affected by the small Paracas Peninsula. Minor near-surface motion was triggered along coastline-parallel reverse faults in the forearc (Audin et al., 2007).

The $1996 M_{w} 7.7$ Nazca earthquake originated on the southeast side of the subducting Nazca Ridge and broke a 200 km segment of the plate boundary. The event ruptured beneath the coastline in a region dominated by strongly positive TPGA, but its peak slip did occur in a local minimum of the TPGA field (Figure 12), also consistent with the observations of Llenos and McGuire (2007). There are no peninsulas, changes in coastline morphology, or faults perpendicular to the coastline within the rupture area. The southeast termination of the 1996 rupture coincides with a strongly positive TPGA, which 
separates this earthquake from the 2001 rupture area to the southeast.

The rupture area of the $2001 M_{w} 8.5$ Arequipa earthquake ends near the Ilo Peninsula and onshore Chololo Fault System (e.g., Audin et al., 2008). The rupture zone lies within a region of dominantly negative TPGA, yet the peak slip occurred within a near-trench local maximum in TPGA. The Chololo Fault System may have affected the rupture pattern by partitioning slip between the megathrust and upper plate structures (Audin et al., 2008). Such influence may give rise to bimodal behavior in seismicity in which massive $\left(M_{w} \sim 9\right)$ earthquakes break the plate interface from the northern extent of the Arequipa rupture zone all the way to the Peru-Chile border (Comte and Pardo, 1991), while 2001-type events rupture the northwestern $\sim 2 / 3$ of that region. The type of earthquake that marks the end of any given seismic cycle on the segment may be dictated not just by the state of stress on the megathrust, but also the stress on the upper plate structures. That is, if slip on the upper plate faults can be triggered by the megathrust rupture, the smaller earthquake may occur, whereas if the physical conditions on the upper plate structures are not appropriate for triggered failure, through-going rupture may occur and give rise to the truly massive earthquakes inferred to have occurred in 1604, 1784, and 1868 (Dorbath et al., 1990; Comte and Pardo, 1991).

The 2007 Tocopilla event initiated $50 \mathrm{~km}$ south of southernmost major eastwest striking reverse fault mapped by Allmendinger et al. (2005a) and terminated at the Mejillones Peninsula. Because the rupture was under land, the location of the coastline seems to have had little impact on the rupture. While we can not calculate the TPGA over most of the rupture, the rupture did seem to occur exclusively downdip of the high TPGA just north of the Mejillones Peninsula, which reflects a tilted crustal block with a morphology similar to 
that of the peninsula (von Huene and Ranero, 2003). On the other hand, the rupture did occur in an area with high IRA, although the magnitude of slip does not appear correlated with the magnitude of the isostatic anomaly.

The 1995 Antofagasta rupture began beneath the Mejillones Peninsula and ruptured southward, reaching maximum slip in a region of negative TPGA that is sandwiched between two regions of positive TPGA. The down-dip termination of the rupture appears to be correlated with strongly positive IRA, while updip slip may have been arrested by the Antofagasta Ridge (Figure 7), which appears as a TPGA high seaward of the slip concentration.

Because the 1998 Antofagasta was a small, moderately deep earthquake, it is hard to find correlations between its rupture and the various physical properties. In addition, the earthquake was entirely beneath land. It ruptured down-dip of the 1995 earthquake in an area of positive IRA.

\subsection{Seismogenesis and seismic segmentation}

Returning to the processes that might be occurring at two different timescales: 1) the seismogenesis of individual earthquakes $\left(10^{1}-10^{3}\right.$ years $)$; and 2$)$ integrated effects of several individual earthquakes defining seismic segments ( $>10^{3}$ years), we ask, is the seismic segmentation concept valid at either timescale? During recorded events in southern Peru and northern Chile, there do appear to be some long-lived segment boundaries (e.g., Nazca Ridge, Mejillones Peninsula, possibly the Ilo Peninsula/Chololo Fault zone), although ruptures may occasionally pass across them. While these features appear to be effective seismic segment boundaries, in some cases it remains unclear which 
defining characteristic is most effective in arresting rupture. For example, while the Mejillones Peninsula serves as the boundary between earthquakes on the Antofagasta and Iquique segments, including the 1995, 2007, and probably the 1877 events, it is not clear what about the peninsula makes it an effective barrier to slip. As noted by Pritchard and Simons (2006), frictional conditions beneath the peninsula permitted substantial afterslip following the 1995 earthquake, and so unique properties of the interface may segment the plate boundary. The positive TPGA signal surrounding the peninsula is also consistent with little great earthquake slip. Furthermore, the offshore margin-normal transverse faults noted by von Huene and Ranero (2003) may also contribute to segmentation in a style similar to that proposed by Audin et al. (2008) for the interaction between the 2001 Arequipa earthquake and the Chololo Fault System.

While several different factors may influence patterns of seismogenesis, the most broadly applicable in our study area appears to be the gravity field and gradients in gravity, although these parameters do show imperfect correlation with earthquake slip distributions (Table 4). Gravity anomalies can reflect a combination of different characteristics that include lower-plate, upper-plate, and interface properties, which may all play a part in seismogenesis and segmentation. In some places, we can differentiate more clearly between the physical mechanisms. For example, upper plate faults influence rupture patterns near the Ilo Peninsula and along the northern Andean margin, but the influence of the east-west striking faults along the Iquique segment remains to be seen. Bathymetric features may be important in creating barriers to rupture during the 2001 earthquake (Robinson et al., 2006) and serve to segment the margin between the 2007 Pisco and 1996 earthquakes. It is also possible 
that the presence of submerged ridges around the Mejillones Peninsula limited the depth extent of slip during the 2007 Tocopilla and 1995 Antofagasta events. When we consider both southern Peru and northern Chile, we conclude that topography and surface uplift of the onshore coastal region are not reliable predictors of coseismic uplift (and therefore slip), although the correlation between coseismic and long-term uplift near the 1996 Peru earthquake is interesting.

\subsection{Forecasts for the 1868-1877 gap}

Based on our findings, we suggest that the remainder of the Iquique segment will likely rupture in a $M_{w}>8.5$ earthquake, and the southernmost Peru segment will break from the Ilo Peninsula to the Peru-Chile border region in a $M_{w}$ 7-7.5 event within the next several decades. The small gap between the 1996 Nazca earthquake and the concentration of coseismic slip during the 2001 Arequipa event may also break in a $M_{w}>7.5$ earthquake, repeating that which occurred in 1913 (Kelleher, 1972; Pritchard et al., 2007). We forecast that these earthquakes will rupture from north to south (Pritchard et al., 2007) and, if the amount of sediments does control the afterslip properties, we would predict there to be little afterslip (perhaps less than $20 \%$ of the coseismic moment) following the earthquake that ruptures the 1868 and 1877 gaps (Pritchard and Simons, 2006). In 100-150 years, at the end of the next seismic cycle, the plate boundary of southern Peru may break in a fashion similar to the 1604, 1784, and 1868 great earthquakes, with slip occurring exclusively on the plate interface rather than some being partitioned onto crustal structures. 


\section{Acknowledgments}

E. Hetland, guest associate editor N. Bangs, and an anonymous referee provided careful reviews that helped to improve the paper. We thank M. Simons

and members of the Cornell Andes Project (especially R. Allmendinger, S. Kay, B. Isacks, and L. Brown) for useful discussions over the years. We thank C. Ji for the seismic analysis software. ERS and Envisat SAR imagery were acquired under ESA Category 1-3194 Project. ALOS data was provided by the Alaska Satellite Facility and JAXA. Software to process ALOS data in ROI_PAC was provided by D. Sandwell, R. Mellors, M. Wei, Y. Fialko, and E. Fielding. The GMT program was used to create most figures (Wessel and Smith, 1998). M.E.P. was partly supported by NSF grant EAR 0510719.

\section{Appendix: Modeling details}

We use the ROI_PAC software for InSAR processing (Rosen et al., 2004). We reduce the number of data points in the interferograms from millions to thousands by subsampling a spatially compressed interferogram (approximately $1 \mathrm{~km}$ per pixel) with a density of points proportional to the displacement field (Simons et al., 2002). Interferograms were unwrapped using the conventional ROI_PAC algorithm (Goldstein et al., 1988). A Digital Elevation Model (DEM) from the Shuttle Radar Topography Mission with 90 m pixel spacing was used to remove the topographic signature from the InSAR phase (Farr and Kobrick, 2000). Because of orbital errors in the ALOS data, we empirically estimate the baselines for the data processed in ROI_PAC by solving for the baseline parameters (e.g., horizontal and vertical baselines parameterized 
as quadratic functions of time on orbit, Pritchard et al., 2002) that minimize the phase difference between the interferogram and a synthetic interferogram made with a DEM after removing a preliminary model of coseismic deformation.

As we have found in our previous studies of subduction zone earthquakes in the area, the quality of the interferograms is generally excellent because of the arid climate on the coast of Chile and Peru. However, we did not use two tracks of ALOS data (paths 104 and 105) because of north-west trending distortions that affect both the InSAR phase and coherence. Similar distortions have been seen in northern Chile with C-band radar data (Pritchard, 2003), but are not apparent in the InSAR data used in the modeling. Because of the timing (between 8 pm and 2 am local time), location within 20 degrees of the magnetic equator, and orientation approximately parallel to the local magnetic field, we suspect that the distortions are of ionospheric origin (e.g. Gray et al., 2000; Xu et al., 2004)

The InSAR data span different time intervals and include up to one month of postseismic deformation (Table 2). However, based on our analysis of postseismic interferograms and previous experiences with subduction earthquakes in the area (e.g., Pritchard and Simons, 2006), we do not think that postseismic deformation contributes more than a few percent of the deformation we observe.

During the inversion, the relative weighting of the data misfit, smoothing and moment minimization in the Ji et al. (2002) method are determined empirically by running many models with different values. We constrain the seismic moment to be near the unconstrained geodetic moment. As we found for the 
2001 and 2007 Peru earthquakes (Pritchard et al., 2007; Pritchard and Fielding, 2008), a larger moment does not significantly improve the fit to the seismic waveforms and allows for fault slip in areas that are not well-constrained by the geodetic data (e.g., at great depth or near the trench). Some tests of the resolving power of the technique are in Ji et al. (2002), and a discussion of combining seismic and InSAR data can be found in Pritchard et al. (2006, 2007).

We also test a variety of different relative weights between the different InSAR datasets. We first perform inversions with each InSAR dataset separately and calculate the RMS. We then pick relative weights that keep the RMS from the combined InSAR inversion as close as possible to the RMS of the individual inversions. In the end, we did not weight any InSAR dataset more than any other. A similar approach is used in determining the relative weighting between the seismic and geodetic data. We weight the InSAR data 10 times more than the default weighting in the Ji et al. (2002) method.

We use our inversions to create forward models of the vertical deformation, and we have several methods for assessing the accuracy of these models. The 2001 and 1995 earthquakes had GPS observations (Ruegg et al., 1996; Klotz et al., 1999; Pritchard et al., 2007) that were used in the inversion and were compared directly to the InSAR data. The vertical displacement is the least precise GPS component and not all 2001 stations had a reliable vertical displacement, but we were generally able to fit the vertical data within $2 \mathrm{~cm}$ for the 1995 earthquake (Pritchard et al., 2002) and $3 \mathrm{~cm}$ for the 2001 earthquake (Pritchard et al., 2007). For the 2007 Pisco earthquake, our model predicts the maximum subaerial vertical deformation to be about $30 \mathrm{~cm}$ of subsidence, which agrees with the field observation of no vertical deformation beyond the 
$40 \mathrm{~cm}$ tidal zone (Audin et al., 2007). Finally, Pritchard et al. (2002) compare the coseismic uplift of coralline algae at 27 points along the coast measured by Ortlieb et al. (1996a), and revised by Ortlieb (personal communication, 2000), with the predicted uplift from our preferred model (Figure 9). The RMS difference is $10.9 \mathrm{~cm}$, but if we remove the data point (near Punta Tetas) with the largest residual, the RMS difference is $6.8 \mathrm{~cm}$. Ortlieb et al. (1996a) do not specify errors for each measurement but estimate an overall precision of $2 \mathrm{~cm}$. We do not understand why the difference between our model and the corraline algae is so large, but we speculate that the measurement error bars might be larger than $2 \mathrm{~cm}$. In summary, we estimate the accuracy of our vertical deformation predictions to be of the order $5 \mathrm{~cm}$ or better.

\section{References}

Abercrombie, R. E., Antolik, M., Felzer, K., Ekström, G., 2001. The 1994 Java tsunami earthquake: Slip over a subducting seamount. Journal of Geophysical Research 106, 6595-6608.

Aki, K., 1979. Characterization of barriers on an earthquake fault. Journal of Geophysical Research 84, 6140-6148.

Allmendinger, R. W., González, G., Yu, J. S., Hoke, G. D., Isacks, B. L., 2005a. Trench-parallel shortening in the Northern Chilean forearc: Tectonic and climatic implications. Bulletin of the Geological Society of America 117 (1/2), 89-104, doi:10.1130/B25505.1.

Allmendinger, R. W., Smalley Jr., R., Bevis, M., Caprio, H., Brooks, B., 2005b. Bending the Bolivian orocline in real time. Geology 33 (11), 905-908, doi:10.1130/G21779.1.

ANCORP Working Group, 1999. Seismic reflection image revealing offset of Andean subduction-zone earthquake locations into oceanic mantle. Nature 397, 341-344.

Angermann, D., Klotz, J., Reigber, C., 1999. Space-geodetic estimation of the Nazca-South America Euler vector. Earth and Planetary Science Letters 171 (329-334).

Audin, L., Lacan, P., Tavera, H., Bondoux, F., 2008. Upper plate deformation and seismic barrier in front of Nazca subduction zone: The Chololo Fault System and active tectonics along the Coastal Cordillera, southern Peru. Tectonophysics 454, In press, doi:10.1016/j.tecto.2007.11.070. 
Audin, L., Perfettini, H., Avouac, J., Farber, D., de la Cruz, D., Chlieh, M., 2007. The 2007 Pisco earthquake $(\mathrm{Mw}=8.0)$, central Peru: Preliminary field investigations and seismotectonic context. Eos Transactions, AGU 88 (52), Fall Meeting Supplement, Abstract T33E-02.

Beck, S., Barrientos, S., Kausel, E., Reyes, M., 1998. Source characteristics of historic earthquakes along the central Chile subduction zone. Journal of South American Earth Sciences 11 (2), 115-129.

Beck, S., Ruff, L. J., 1989. Great earthquakes and subduction along the Peru trench. Physics of the Earth and Planetary Interiors 57, 199-224.

Beck, S. L., Nishenko, S. P., 1990. Variations in the mode of great earthquake rupture along the central Peru subduction zone. Geophysical Research Letters 17 (11), 1969-1972.

Bevis, M., Kendrick, E., Smalley Jr., R., Brooks, B., Allmendinger, R. W., Isacks, B. L., 2001. On the strength of interplate coupling and the rate of back arc convergence in the central Andes: An analysis of the interseismic velocity field. Geochemistry, Geophysics, Geosystems 2, doi:10.1029/2001GC000198.

Bilek, S. L., Lay, T., 2002. Tsunami earthquakes possibly widespread manifestations of frictional conditional stability. Geophysical Research Letters 29 (14), 1673, doi:10.1029/2002GL015215.

Bilek, S. L., Schwartz, S. Y., DeShon, H. R., 2003. Controls of seafloor roughness on earthquake rupture behavior. Geology 31 (5), 455-458, doi:10.1130/0091-7613(2003)031<0455:COSROE $>2.0$.CO;2.

Brudzinski, M. R., Allen, R. M., 2007. Segmentation in episodic tremor and slip all along Cascadia. Geology 35 (10), 907-910, doi:10.1130/G23740A.1.

Bürgmann, R., Kogan, M. G., Steblov, G. M., Hilley, G., Levin, V. E., Apel, E., 2005. Interseismic coupling and asperity distribution along the Kamchatka subduction zone. Journal of Geophysical Research 110, B07405, doi:10.1029/2005JB003648.

Butler, R., Lay, T., Creager, K., Earl, P., Fisher, K., Gaherty, J., Laske, G., Leith, B., Park, J., Ritzwoller, M., Tromp, J., Wen, L., 2004. The Global Seismographic Network surpasses its design goal. Eos 85 (23), 225.

Carrizo, D., González, G., Dunai, T., 2008. Constricción neógena en la cordillera de la costa norte de Chile: Neotectónica y datación de superficies con ${ }^{21} \mathrm{Ne}$ cosmogénico. Revista Geológica de Chile 35 (1), 1-38.

Casanova, C., Pinter, N., Radtke, U., 2006a. New elevation data and ages from late-Neogene coastal terrace sequence in Mejillones Peninsula Northern Chile: Reconstructing the morphotectonic evolution along a segment of the Nazca subduction zone. Geophysical Research Abstracts 8, 09951.

Casanova, C., Pinter, N., Radtke, U., Ishman, S., 2006b. Secuencia de terrazas costeras en el extremo norte de la península de Mejillones, norte de Chile: Nueva caracterización espacial y estimación de edades usando electron spin resonance (ESR) en moluscos. In: XI Congreso Geológico Chileno. Vol. 2. Antofagasta, Chile, pp. 379-382.

Cisternas, M., Atwater, B. F., Torrejon, F., Sawai, Y., Machuca, G., Lagos, 
M., Eipert, A., Youlton, C., Salgado, I., Kamataki, T., Shishikura, M., Rajendran, C. P., Malik, J. K., Rizal, Y., Husni, M., 2005. Predecessors of the giant 1960 Chile earthquake. Nature 437, 404-407, doi:10.1038/nature03943.

Cloos, M., 1992. Thrust-type subduction-zone earthquakes and seamount asperities: A physical model for seismic rupture. Geology 20, 601-604.

Collot, J.-Y., Marcaillou, B., Sage, F., Michaud, F., Agudelo, W., Charvis, P., Graindorge, D., Gutscher, M.-A., Spence, G., 2004. Are rupture zone limits of great subduction earthquakes controlled by upper plate structures? Evidence from multichannel seismic reflection data acquired across the northern Ecuador-southwest Colombia margin. Journal of Geophysical Research 109, B11103, doi:10.1029/2004JB003060.

Comte, D., Eisenber, A., Lorca, E., Pardo, M., Ponce, L., Saragoni, R., Singh, S., Suarez, G., 1986. The 1985 central Chile earthquake: A repeat of previous great earthquakes in the region? Science 233, 449-453.

Comte, D., Pardo, M., 1991. Reappraisal of great historical earthquakes in the northern Chile and southern Peru seismic gaps. Natural Hazards 4 (1), 23-44, doi:10.1007/BF00126557.

Das, S., Aki, K., 1977. Fault plane with barriers: A versatile earthquake model. Journal of Geophysical Research 82, 5658-5670.

Delouis, B., Monfret, T., Dorbath, L., Pardo, M., Rivera, L., Comte, D., Haessler, H., Caminade, J. P., Ponce, L., Kausel, E., Cisternas, A., 1997. The $\mathrm{M}_{W}=8.0$ Antofagasta (Northern Chile) earthquake of 30 July 1995: A precursor to the end of the large 1877 gap. Bulletin of the Seismological Society of America 87 (2), 427-445.

Delouis, B., Philip, H., Dorbath, L., Cisternas, A., 1998. Recent crustal deformation in the Antofagasta region (northern Chile) and the subduction process. Geophysical Journal International 132, 302-338, doi:10.1046/j.1365246x.1998.00439.x.

Dorbath, L., Cisternas, A., Dorbath, C., 1990. Quantitative assessment of great earthquakes in Peru. Bulletin of the Seismological Society of America $80,551-576$.

Farr, T. G., Kobrick, M., 2000. Shuttle Radar Topography Mission produces a wealth of data. Eos Transactions, AGU 81, 583-585.

Gephart, J. W., 1994. Topography and subduction geometry in the Central Andes: Clues to the mechanics of a non-collisional orogen. Journal of Geophysical Research 99 (B6), 12279-12288.

Giovanni, M., Beck, S., Wagner, L., 2002. The June 23, 2001 Peru earthquake and the southern Peru subduction zone. Geophysical Research Letters 29 (21), 2018, doi:10.1029/2002GL015774.

Goldstein, R. M., Zebker, H. A., Werner, C. L., 1988. Satellite radar interferometry two-dimensional phase unwrapping. Radio Science 23, 713-720.

González, G., Wilke, H., Marquardt, C., 2006. Neotectónica de la peninsula Mejillones (field guide). In: XI Congreso Geológico Chileno. Universidad Católica del Norte, Antofagasta, Chile.

Gray, A.L., Mattar, K.E., Sofko, G., 2000. Influence of ionospheric electron 
density fluctuations on satellite radar interferometry. Geophysical Research Letters, 27 (10), 1451-1454.

Hagen, R. A., Moberly, R., 1994. Tectonic effects of a subducting aseismic ridge: The subduction of the Nazca Ridge at the Peru Trench. Marine Geophysics Researches 16, 145-161.

Hampel, A., 2002. The migration history of the Nazca Ridge along the Peruvian active margin: a re-evaluation. Earth and Planetary Science Letters 203, 665-679, doi:10.1016/S0012-821X(02)00859-2.

Hampel, A., Kukowski, N., Bialas, J., Huebscher, C., Heinbockel, R., 2004. Ridge subduction at an erosive margin: The collision zone of the Nazca Ridge in southern Peru. Journal of Geophysical Research 109, b02101, doi:10.1029/2003JB002593.

Hoffmann-Rothe, A., Kukowski, N., Dresen, G., Echtler, H., Oncken, O., Klotz, J., Scheuber, E., Kellner, A., 2006. Oblique Convergence along the Chilean Margin: Partitioning, Margin-Parallel Faulting and Force Interaction at the Plate Interface. In: Oncken, O., Chong, G., Franz, G., Giese, P., Götze, H.J., Ramos, V. A., Strecker, M. R., Wigger, P. (Eds.), The Andes. Springer, pp. 125-146, doi:10.1007/978-3-540-48684-8_6.

Hsu, J. T., 1992. Quaternary uplift of the Peruvian coast related to the subduction of the Nazca Ridge: 13.5 to 15.6 degrees south latitude. Quaternary Science Review 15, 87-97.

Husen, S., Kissling, E., Flueh, E., Asch, G., 1999. Accurate hypocentre determination in the seismogenic zone of the subducting Nazca Plate in northern Chile using a combined on-/offshore network. Geophysical Journal International 138 (3), 687-701, doi:10.1046/j.1365-246x.1999.00893.x.

Igarashi, T., Matsuzawa, T., Hasegawa, A., 2003. Repeating earthquakes and interplate aseismic slip in the northeastern Japan subduction zone. Journal of Geophysical Research 108, 2249, doi:10.1029/2002JB001920.

Ihmlé, P. F., Ruegg, J., 1997. Source tomography by simulated annealing using broad-band surface waves and geodetic data: Application to the $M_{w}=8.1$ Chile 1995 event. Geophysical Journal International 131, 146-158.

Isacks, B. L., 1988. Uplift of the Central Andean Plateau and bending of the Bolivian Orocline. Journal of Geophysical Research 93 (4), 3211-3231.

Ji, C., Wald, D. J., Helmberger, D. V., May 2002. Source description of the 1999 Hector Mine, California, earthquake, part I: Wavelet domain inversion theory and resolution analysis. Bulletin of the Seismological Society of America 92, 1192-1207, doi:10.1785/0120000916.

Kanamori, H., 1986. Rupture process of subduction-zone earthquakes. Annual Reviews of Earth and Planetary Science 14, 293-322.

Kanamori, H., McNally, K., 1982. Variable rutpure mode of the subduction zone along the Ecuador-Columbia coast. Bulletin of the Seismological Society of America 72, 1241-1253.

Kelleher, J., McCann, W., 1976. Buoyant zones, great earthquakes, and unstable boundaries of subduction. Journal of Geophysical Research 81 (26), 4885-4896. 
Kelleher, J. A., 1972. Rupture zones of large South American earthquakes and some predictions. Journal of Geophysical Research 77 (11), 2087-2103.

Klotz, J., Angermann, D., Michel, G. W., Porth, R., Reigber, C., Reinking, J., Viramonte, J., Perdomo, R., Rios, V. H., Barrientos, S., Barriga, R., Cifuentes, O., 1999. GPS-derived deformation of the Central Andes including the 1995 Antofagasta $M_{w}=8.0$ earthquake. Pure and Applied Geophysics 154, 709-730, doi:10.1007/s000240050249.

Kodaira, S., Hori, T., Ito, A., Miura, S., Fujie, G., Park, J.-O., Baba, T., Sakaguchi, H., , Kaneda, Y., 2006. A cause of rupture segmentation and synchronization in the Nankai trough revealed by seismic imaging and numerical simulation. Journal of Geophysical Research 111, B09301, doi:10.1029/2005JB004030.

Kodaira, S., Takahashi, N., Nakanishi, A., Miura, S., Kaneda, Y., 2000. Subducted Seamount Imaged in the Rupture Zone of the 1946 Nankaido Earthquake. Science 289, 104-106, doi:10.1126/science.289.5476.104.

Krabbenhöft, A., Bialas, J., Kopp, H., Kukowski, N., Hübscher, C., 2004. Crustal structure of the Peruvian continental margin from wide-angle seismic studies. Geophysical Journal International 159 (2), 749-764, doi:10.1111/j.1365-246X.2004.02425.x.

Kukowski, N., Hampel, A., Hoth, S., Bialas, J., 2008. Morphotectonic and morphometric analysis of the Nazca plate and the adjacent offshore Peruvian continental slope - Implications for submarine landscape evolution. Marine Geology In press, doi:10.1016/j.margeo.2008.05.017.

Laursen, J., Scholl, D. W., von Huene, R., 2002. Neotectonic deformation of the central Chile margin: Deepwater forearc basin formation in response to hot spot ridge and seamount subduction. Tectonics 21 (5), 1038, doi:10.1029/2001TC901023.

Lay, T., Kanamori, H., 1981. An asperity model of great earthquake sequences. In: Simpson, D., Richards, P. (Eds.), Earthquake Prediction: An International Review. No. 4 in Maurice Ewing Series. American Geophysical Union, Washington, D.C., pp. 579-592.

Llenos, A., McGuire, J., 2007. Influence of fore-arc structure on the extent of great subduction zone earthquakes. Journal of Geophysical Research 112, B09301, doi:10.1029/2007JB004944.

Loveless, J. P. and Pritchard, M. E., 2008. Motion on upper-plate faults during strong subduction zone earthquakes: Case of the Atacama Fault System, northern Chile. Geochemistry, Geophysics, Geosystems, 9, Q12017, doi:10.1029/2008GC002155.

Loveless, J. P., Allmendinger, R. W., Pritchard, M. E., Garroway, J. L., González, G., 2009. Surface cracks record long-term seismic segmentation of the Andean margin. Geology, 37 (1):2326, doi:10.1130/G25170A.1.

Machare, J., Ortlieb, L., 1992. Plio-Quaternary vertical motions and the subduction of the Nazca Ridge, central coastal Peru. Tectonophysics 205, 97108.

Masson, F., Dorbath, C., Martinez, C., Carlier, G., 2000. Local earthquake 
tomography of the Andes at $20^{\circ} \mathrm{S}$ : Implications for the structure and building of the mountain range. Journal of South American Earth Sciences 13, 3-19.

McCaffrey, R., 1993. On the role of the upper plate in great subduction zone earthquakes. Journal of Geophysical Research 98 (B7), 11953-11966.

McCaffrey, R., 1997. Influences of recurrence times and fault zone temperatures on the age-rate dependence of subduction zone seismicity. Journal of Geophysical Research 102, 22839-22854.

McCaffrey, R., 2007. The Next Great Earthquake. Science 315, 1675-1676, doi:10.1126/science.1140173.

McGlashan, N., Brown, L., Kay, S., 2008. Crustal thickness in the central Andes from teleseismically recorded depth phase precursors. Geophysical Journal International 175 (3), 1013-1022, doi:10.1111/j.1365-246X.2008.03897.x.

Melnick, D., Bookhagen, B., Echtler, H. P., Strecker, M. R., 2006. Coastal deformation and great subduction earthquakes, Isla Santa María, Chile $\left(37^{\circ} \mathrm{S}\right)$. Bulletin of the Geological Society of America 118 (11/12), 14631480, doi:10.1130/B25865.1.

Melnick, D., Bookhagen, B., Strecker, M. R., Echtler, H. P., 2009. Segmentation of megathrust rupture zones from fore-arc deformation patterns over hundreds to millions of years, Arauco peninsula, Chile. Journal of Geophysical Research, 114, B01407, doi:10.1029/2008JB005788.

Miyazaki, S., Segall, P., Fukuda, J., Kato, T., 2004. Space time distribution of afterslip following the 2003 Tokachi-oki earthquake: Implications for variations in fault zone frictional properties. Geophysical Research Letters 31, L06623, doi:10.1029/2003GL019410.

Montero, W., 1986. Periodos de recurrencia y tipos de secuencias sísmicas de los temblores interplaca e intraplaca en la región de Costa Rica. Revista Geológica de America Central 5, 35-72.

Müller, R. D., Roest, W. R., Royer, J.-Y., Gahagan, L. M., Sclater, J. G., 1997. Digital isochrons of the world's ocean floor. Journal of Geophysical Research 102, 3211-3214.

Natawidjaja, D., Sieh, K., Chlieh, M., Galetzka, J., Suwargadi, B., Cheng, H., Edwards, R. L., Avouac, J. P., Ward, S., 2006. Source parameters of the great Sumatran megathrust earthquakes of 1797 and 1833 inferred from coral microatolls. Journal of Geophysical Research 109, B04306, doi:10.1029/2003JB002398.

Nelson, A. R., Kelsey, H. M., Witter, R. C., 2006. Great earthquakes of variable magnitude at the Cascadia subduction zone. Quaternary Research 65, 354365.

Newman, A. V., Schwartz, S. Y., Gonzalez, V., DeShon, H. R., Protti, J. M., Dorman, L. M., 2002. Along-strike variability in the seismogenic zone below Nicoya Peninsula, Costa Rica. Geophysical Research Letters 29, 1977, doi:10.1029/2002GL015409.

Niemeyer, H., González, G., Martinez-de los Ríos, E., 1996. Evolución tectónica cenozoica del margen continental activo de Antofagasta, norte 
de Chile. Revista Geológica de Chile 23 (2), 165-186.

Okada, T., Yaginuma, T., Umino, N., Kono, T., Matsuzawa, T., Kita, S., Hasegawa, A., 2005. The 2005 M7.2 MIYAGI-OKI earthquake, NE Japan: Possible rerupturing of one of asperities that caused the previous M7.4 earthquake. Geophysical Research Letters 32, L24302, doi:10.1029/2005GL024613.

Okal, E. A., Borrero, J. C., Synolakis, C. E., 2006. Evaluation of tsunami risk from regional earthquakes at Pisco, Peru. Bulletin of the Seismological Society of America 96 (5), 1634-1648, doi:10.1785/0120050158.

Oleskevich, D. A., Hyndman, R. D., Wang, K., 1999. The updip and downdip limits to great subduction earthquakes: Thermal and structural models of Cascadia, south Alaska, SW Japan, and Chile. Journal of Geophysical Research 104 (B7), 14965-14991, doi:10.1029/1999JB900060.

Ortlieb, L., Barrientos, S., Guzman, N., 1996a. Coseismic coastal uplift and coralline algae record in northern Chile: the 1995 Antofagasta earthquake case. Quaternary Science Reviews 15 (8-9), 949-960.

Ortlieb, L., Zazo, C., Goy, J. L., Hillaire-Marcel, C., Ghaleb, B., Cournoyer, L., 1996b. Coastal deformation and sea-level changes in the northern Chile subduction area $\left(23^{\circ} \mathrm{S}\right)$ during the last 330 ky. Quaternary Science Reviews 15, 819-831.

Pacheco, J. F., Sykes, L. R., Scholz, C. H., 1993. Nature of seismic coupling along simple plate boundaries of the subduction type. Journal of Geophysical Research 98, 14133-14159.

Park, S.-C., Mori, J., 2007. Are asperity patterns persistent? Implication from large earthquakes in Papua New Guinea. Journal of Geophysical Research 112, B03303, doi:10.1029/2006JB004481.

Pritchard, M.E., 2003. Recent crustal deformation in west-central South America. PhD. thesis, California Institute of Technology, Pasadena, CA, http://etd.caltech.edu/etd/available/etd-06022003-105512/.

Pritchard, M. E., Fielding, E. J., 2008. A study of the 2006 and 2007 earthquake sequence of Pisco, Peru, with InSAR and teleseismic data. Geophysical Research Letters In press, doi:10.1029/2008GL033374.

Pritchard, M. E., Ji, C., Simons, M., 2006. Distribution of slip from $11 M_{w}>6$ earthquakes in the northern Chile subduction zone. Journal of Geophysical Research 111, B10302, doi:10.1029/2005JB004013.

Pritchard, M. E., Norabuena, E. O., Ji, C., Boroschek, R., Comte, D., Simons, M., Dixon, T., Rosen, P. A., 2007. Geodetic, teleseismic, and strong motion constraints on slip from recent southern Peru subduction zone earthquakes. Journal of Geophysical Research 112, B03307, doi:10.1029/2006JB004294.

Pritchard, M. E., Simons, M., 2006. An aseismic slip pulse in northern Chile and along-strike variations in seismogenic behavior. Journal of Geophysical Research 111, B08405, doi:10.1029/2006JB004258.

Pritchard, M. E., Simons, M., Rosen, P. A., Hensley, S., Webb, F. H., 2002. Co-seismic slip from the 1995 July $30 M_{w}=8.1$ Antofagasta, Chile earthquake as constrained by InSAR and GPS observations. Geophysical Journal 
International 150, 362-376, doi:10.1046/j.1365-246X.2002.01661.x.

Ramírez-Herrera, M.-T., Urritia-Fucugauchi, J., 1999. Morphotectonic zones along the coast of the Pacific continental margin, southern Mexico. Geomorphology 28 (3-4), 237-250, doi:10.1016/S0169-555X(99)00016-1.

Ranero, C. R., von Huene, R., 2000. Subduction erosion along the Middle America convergent margin. Nature 404 (6779), 748-752, doi:10.1038/35008046.

Rehak, K., Strecker, M. R., Echtler, H. P., 2008. Morphotectonic segmentation of an active forearc, $37^{\circ}-41^{\circ} \mathrm{S}$, Chile. Geomorphology 94, 98-116, doi:10.1016/j.geomorph.2007.05.002.

Robinson, D., Das, S., Watts, A., 2006. Earthquake rupture stalled by a subducting fracture zone. Science 312, 1203-1205, doi:10.1126/science.1125771.

Rosen, P. A., Hensley, S., Peltzer, G., Simons, M., 2004. Updated Repeat Orbit Interferometry Package released. EOS Transactions, AGU 85 (5), 47.

Ruegg, J., Campos, J., Armijo, R., Barrientos, S., Briole, P., Thiele, R., Arancibia, M., Cañuta, J., Duquesnoy, T., Chang, M., Lazo, D., Lyon-Caen, H., Ortlieb, L., Rossignol, J., Serruier, L., 1996. The $M_{w}=8.1$ Antofagasta (North Chile) Earthquake of July 30, 1995: First results from teleseismic and geodetic data. Geophysical Research Letters 23 (9), 917-920.

Ruff, L. J., 1989. Do trench sediments affect great earthquake occurrence in subduction zones? Pure and Applied Geophysics 129 (1/2), 263-282.

Ruff, L. J., Tichelaar, B. W., 1996. What controls the seismogenic plate interface in subduction zones? In: Bebout, G. E., Scholl, D. W., Kirby, S. H., Platt, J. P. (Eds.), Subduction: Top to Bottom, Geophysical Monograph Series. Vol. 96. American Geophysical Union, Washington, D.C., pp. 105112.

Salichon, J., Delouis, B., Lundgren, P., Giardini, D., Costantini, M., Rosen, P., 2003. Joint inversion of broadband teleseismic and interferometric synthetic aperture radar (InSAR) data for the slip history of the $M_{w}=7.7$, Nazca ridge (Peru) earthquake of 12 November 1996. Journal of Geophysical Research 108, 2085, doi:10.1029/2001JB000913.

Sandwell, D. T., Smith, W. H. F., 1997. Marine gravity anomaly from Geosat and ERS-1 satellite altimetry. Journal of Geophysical Research 102 (B5), 10,039-10,054, doi:10.1029/96JB03223.

Satake, K., Hirata, K., Yamaki, S., Tanioka, Y., 2006. Re-estimation of tsunami source of the 1952 Tokachi-oki earthquake. Earth Planets Space $58,535-542$.

Savage, J. C., 1983. A dislocation model of strain accumulation and release at a subduction zone. Journal of Geophysical Research 88 (B6), 4984-4996.

Schenk, C. J., Viger, R. J., Anderson, C. P., 1998. Maps showing geology, oil and gas fields, and geologic provinces of the South America region. USGS Open-file report 97-470D.

Schmidt, S., Götze, H.-J., 2006. Bouguer and isostatic maps of the Central Andes. In: Oncken, O., Chong, G., Franz, G., Giese, P., Götze, H.-J., Ramos, V., Strecker, M., Wigger, P. (Eds.), The Andes - Active Subduction Orogeny. 
Springer-Verlag, pp. 559-562.

Scholz, C. H., 2002. The Mechanics of Earthquakes and Faulting, 2nd Edition. Cambridge University Press, Cambridge.

Scholz, C. H., Campos, J., 1995. On the mechanism of seismic decoupling and back arc spreading at subduction zones. Journal of Geophysical Research 100, 22,103-22,115.

Schwartz, D. P., Coppersmith, K. J., 1984. Fault behavior and characteristic earthquakes: Examples from the wasatch and san andreas fault zones. Journal of Geophysical Research 89 (B7), 5681-5698.

Schwartz, S. Y., 1999. Noncharacteristic behavior and complex recurrence of large subduction zone earthquakes. Journal of Geophysical Research 104 (B10), 23,111-23,125.

Schweller, W. J., Kulm, L. D., Prince, R. A., 1981. Tectonics, structure, and sedimentary framework of the Peru-Chile trench. Geological Society of America Memoir 154, 323-349.

Sick, C., Yoon, M.-K., Rauch, K., Buske, S., Lüth, S., Araneda, M., Bataille, K., Chong, G., Giese, P., Krawczyk, C., Mechie, J., Meyer, H., Oncken, O., Reichert, C., Schmitz, M., Shapiro, S., Stiller, M., Wigger, P., 2006. Seismic Images of Accretive and Erosive Subduction Zones from the Chilean Margin. In: Oncken, O., Chong, G., Franz, G., Giese, P., Götze, H.-J., Ramos, V. A., Strecker, M. R., Wigger, P. (Eds.), The Andes. Springer, pp. 147-169.

Simons, M., Fialko, Y., Rivera, L., 2002. Coseismic deformation from the 1999 $\mathrm{M}_{w}$ 7.1 Hector Mine, California, earthquake as inferred from InSAR and GPS observations. Bulletin of the Seismological Society of America 92 (4), 1390-1402, doi:10.1785/0120000933.

Sladen, A., Konca, A. O., Perfettini, H., Audin, L., Tavera, H., Avouac, J., Simons, M., Helmberger, D. V., 2007. Source characteristics of the 2007 Pisco earthquake $(\mathrm{Mw}=8.0)$, central Peru, derived from seismic waveforms inversion and tsunami modeling. Eos Transactions, AGU 88 (52), Fall Meeting Supplement, Abstract S13A-1055.

Sobiesiak, M., Meyer, U., Schmidt, S., Götze, H.-J., Krawczyk, C. M., 2007. Asperity generating upper crustal sources revealed by b value and isostatic residual anomaly grids in the area of Antofagasta, Chile. Journal of Geophysical Research 112, B12308, doi:10.1029/2006JB004796.

Song, T.-R. A., Simons, M., 2003. Large trench-parallel gravity variations predict seismogenic behavior in subduction zones. Science 301 (5633), 630633, doi:10.1126/science.1085557.

Spence, W., Mendoza, C., Engdahl, E. R., Choy, G. L., Norabuena, E., 1999. Seismic subduction of the Nazca Ridge as shown by the 199697 Peru earthquakes. Pure and Applied Geophysics 154 (3-4), 753-776, doi:10.1007/s000240050251.

Swenson, J., Beck, S. L., 1999. Source characteristics of the 12 November 1996 $M_{w}$ 7.7 Peru subduction zone earthquake. Pure and Applied Geophysics 154 (3-4), 731-751, doi:10.1007/s000240050250.

Tassara, A., Swain, C., Hackney, R., Kirby, J., 2007. Elastic thickness 
structure of South America estimated using wavelets and satellitederived gravity data. Earth and Planetary Science Letters 253, 17-36, doi:10.1016/j.epsl.2006.10.008.

Thatcher, W., 1990. Order and diversity in the modes of circum-Pacific earthquake recurrence. Journal of Geophysical Research 95, 2609-2623.

Tichelaar, B. W., Ruff, L. J., 1991. Seismic coupling along the Chilean subduction zone. Journal of Geophysical Research 96 (B7), 11,997-12,022.

Tichelaar, B. W., Ruff, L. J., 1993. Depth of seismic coupling along subduction zones. Journal of Geophysical Research 98, 2017-2037.

Victor, P., Sobiesiak, M., Nielsen, S. N., Oncken, O., 2006. Subduction earthquake segment boundary expressed in surface deformation of Mejillones Peninsula. In: XI Congreso Geológico Chileno. Vol. 2. Antofagasta, Chile, pp. 473-476.

von Huene, R., Ranero, C. R., 2003. Subduction erosion and basal friction along the sediment-starved convergent margin off Antofagasta, Chile. Journal of Geophysical Research 108 (B2), 2079, doi:10.1029/2001JB001569.

von Huene, R., Weinrebe, W., Heeren, F., 1999. Subduction erosion along the North Chile margin. Journal of Geodynamics 27, 345-358, doi:10.1016/S0264-3707(98)00002-7.

Wells, R. E., Blakely, R. J., Scholl, D. W., 2007. Slip in great megathrust earthquakes and its relation to crustal structure revealed by satellite freeair gravity. EOS Transactions, AGU 88 (52), Fall Meeting Supplement, Abstract T51E-07.

Wells, R. E., Blakely, R. J., Sugiyama, Y., Scholl, D. W., Dinterman, P. A., 2003. Basin-centered asperities in great subduction zone earthquakes: A link between slip, subsidence, and subduction erosion? Journal of Geophysical Research 108 (B10), 2507, doi:10.1029/2002JB002072.

Wessel, P., Smith, W. H. F., 1998. New, improved version of Generic Mapping Tools. EOS Transactions, AGU 79, 579.

Wigger, P. J., Schmitz, M., Araneda, M., Asch, G., Baldzuhn, S., Giese, P., Heinsohn, W. D., Martinez, E., Ricaldi, E., Röwer, P., 1994. Variation in the crustal structure of the southern Central Andes deduced from seismic refraction investigations. In: Reutter, K.-J., Scheuber, E., Wigger, P. J. (Eds.), Tectonics of the Southern Central Andes. Springer-Verlag, pp. 2348.

Xu, Z.W., Wu, J., Wu, Z.S., 2004. A survey of ionospheric effects on spacebased radar. Waves in Random and Complex Media, 14(2),189-273.

Yamanaka, Y., Kikuchi, M., 2004. Asperity map along the subduction zone in northeastern Japan inferred from regional seismic data. Journal of Geophysical Research 109, B07307, doi:10.1029/2003JB002683.

Yuan, X., Sobolev, S. V., Kind, R., 2002. Moho topography in the Central Andes and its geodynamic implications. Earth and Planetary Science Letters 199 (3-4), 389-402.

Zhang, Z., Schwartz, S. Y., 1992. Depth distribution of moment release in underthrusting earthquakes at subduction zones. Journal of Geophysical 
Research 97, 537-544. 


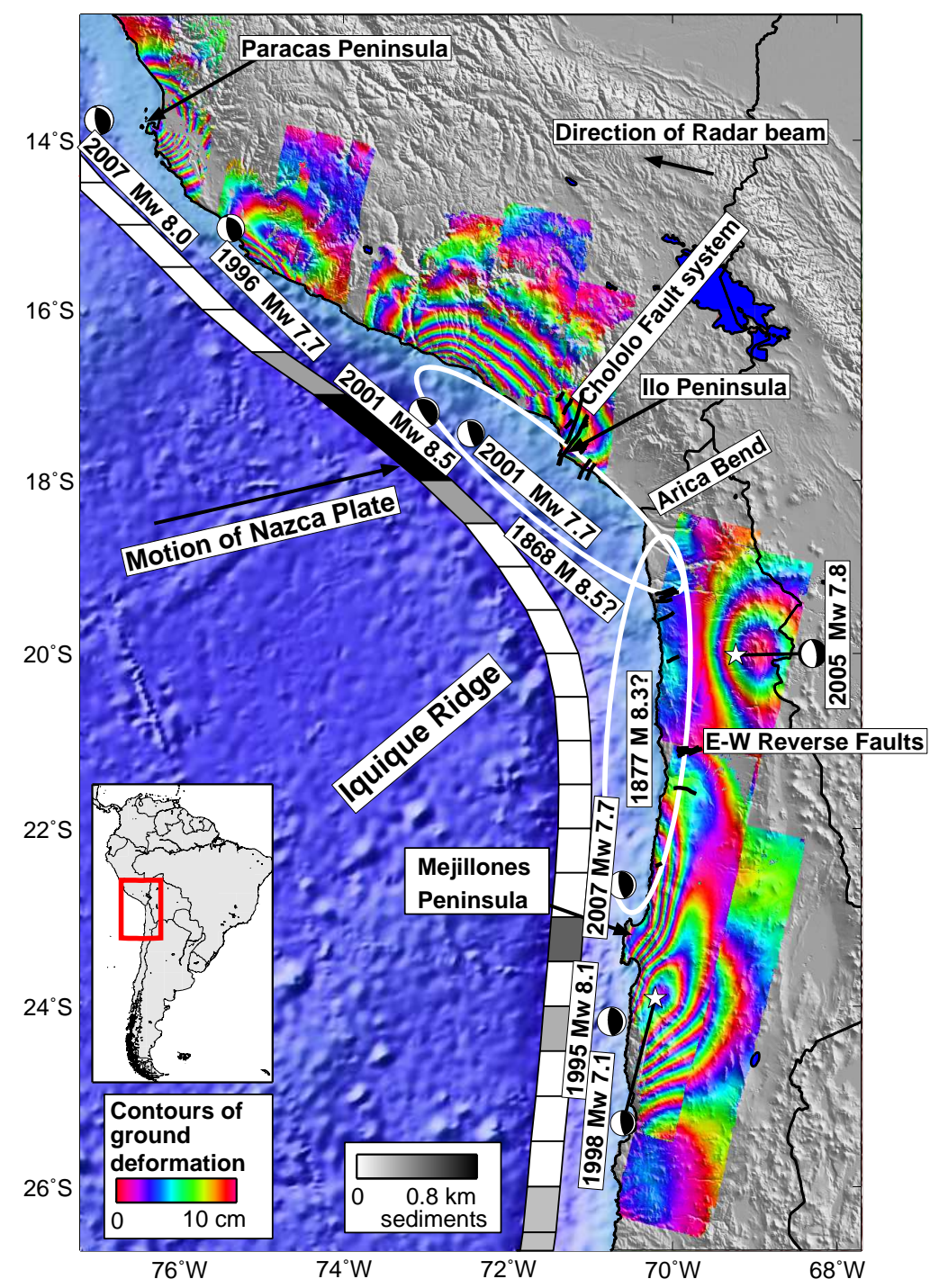

Fig. 1. Deformation from large subduction zone earthquakes in the central Andes between 1992-2007 as measured by the ERS-1, ERS-2, and Envisat radar satellites of the European Space Agency. All scenes have been unwrapped and re-wrapped at a $10 \mathrm{~cm}$ interval (each contour represents a change of $10 \mathrm{~cm}$ in the distance from the satellite and the ground between satellite overflights). The direction of the radar beam is shown by the black arrow at the top of the image. The gray shaded boxes show the maximum amount of trench sediment in every $0.5^{\circ}$ interval (Schweller et al., 1981). We show the focal mechanisms from the Global CMT catalog for the six earthquakes we study here along with the $2005 M_{w} 7.8$ and $2001 M_{w}$ 7.7 earthquakes that we do not discuss. The white ellipses show the approximate rupture areas of the largest earthquakes adjacent to our study area. The size and spatial extent of the 1877 rupture is especially uncertain ( e.g., Comte and Pardo, 1991; Beck et al., 1998). We have labeled peninsulas, tectonic features and seafloor ridges that are mentioned in the text and provide a reference map of South America in the lower left where the study area is shown in red. 


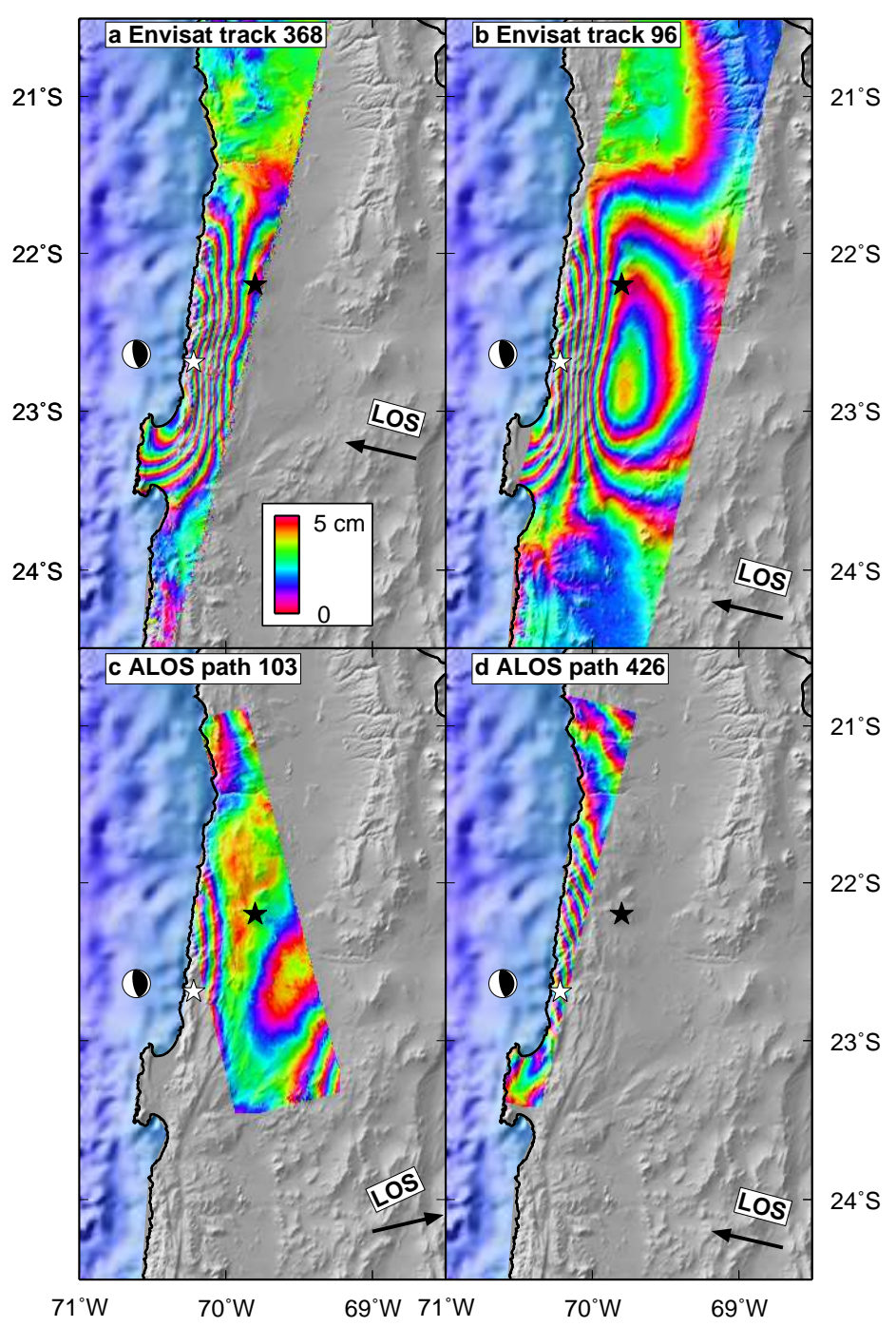

Fig. 2. (a-b) Interferograms from 2 Envisat descending orbital tracks spanning the 2007 earthquake (See Table 2 for dates). (c-d) Interferograms from 2 ALOS orbital tracks (ascending and descending). All scenes have been unwrapped and re-wrapped at a $5 \mathrm{~cm}$ interval. The satellite to ground radar line-of-sight (LOS) is shown with an arrow. The descending interferograms contain more fringes than the ascending ALOS one because the westward and downward coseismic ground motion add constructively for the descending orbits but destructively for the ascending orbits (as observed for the 2001 and Peru and 1995 Chile earthquakes (Pritchard and Simons, 2006; Pritchard et al., 2007)). The largest InSAR displacement observed is about $0.4 \mathrm{~m}$ in the Envisat data and about $0.2 \mathrm{~m}$ in the ALOS data. The USGS hypocenter location is shown as the black star, the DGF solution is the white star and the focal mechanism is from the Global CMT catalog. 


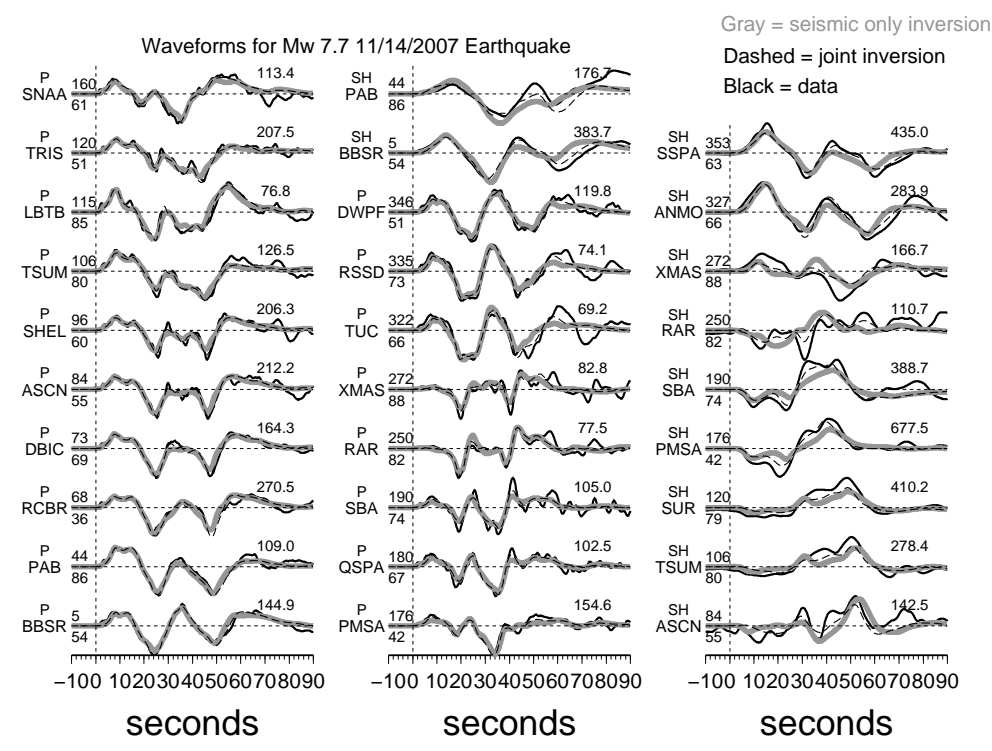

Fig. 3. Teleseismic displacement data ( $\mathrm{P}$ and $\mathrm{SH})$ used in the slip inversions for the 2007 mainshock (black lines) and calculated synthetics from the teleseismic-only (gray lines), and joint inversions (black dashed lines). To the left of each trace is the station name, epicentral distance (lower number) and azimuth (upper number, which increases from the bottom of the page to the top). The type of record ( $\mathrm{P}$ or $\mathrm{SH}$ ) is listed above each station name. Each amplitude has been normalized by the maximum displacement, shown in microns in the upper right of each trace. 


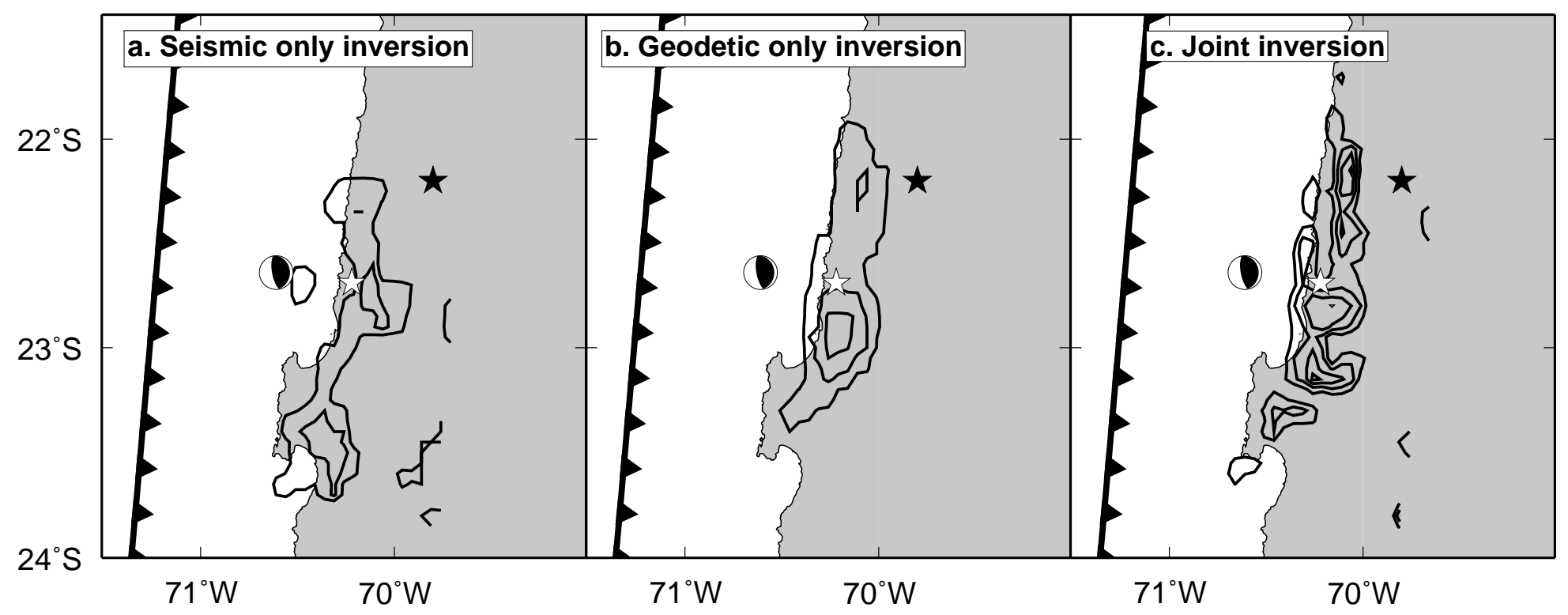

Fig. 4. Contours of slip from the 2007 mainshock from inversions using (a.) only seismic data, (b.) only InSAR data, and (c.) both datasets. The maximum slip is about $3 \mathrm{~m}$ in the joint model and the contour interval is $0.5 \mathrm{~m}$. The USGS hypocenter location is shown as the black star, the DGF solution is the white star and the focal mechanism is from the Global CMT catalog. 


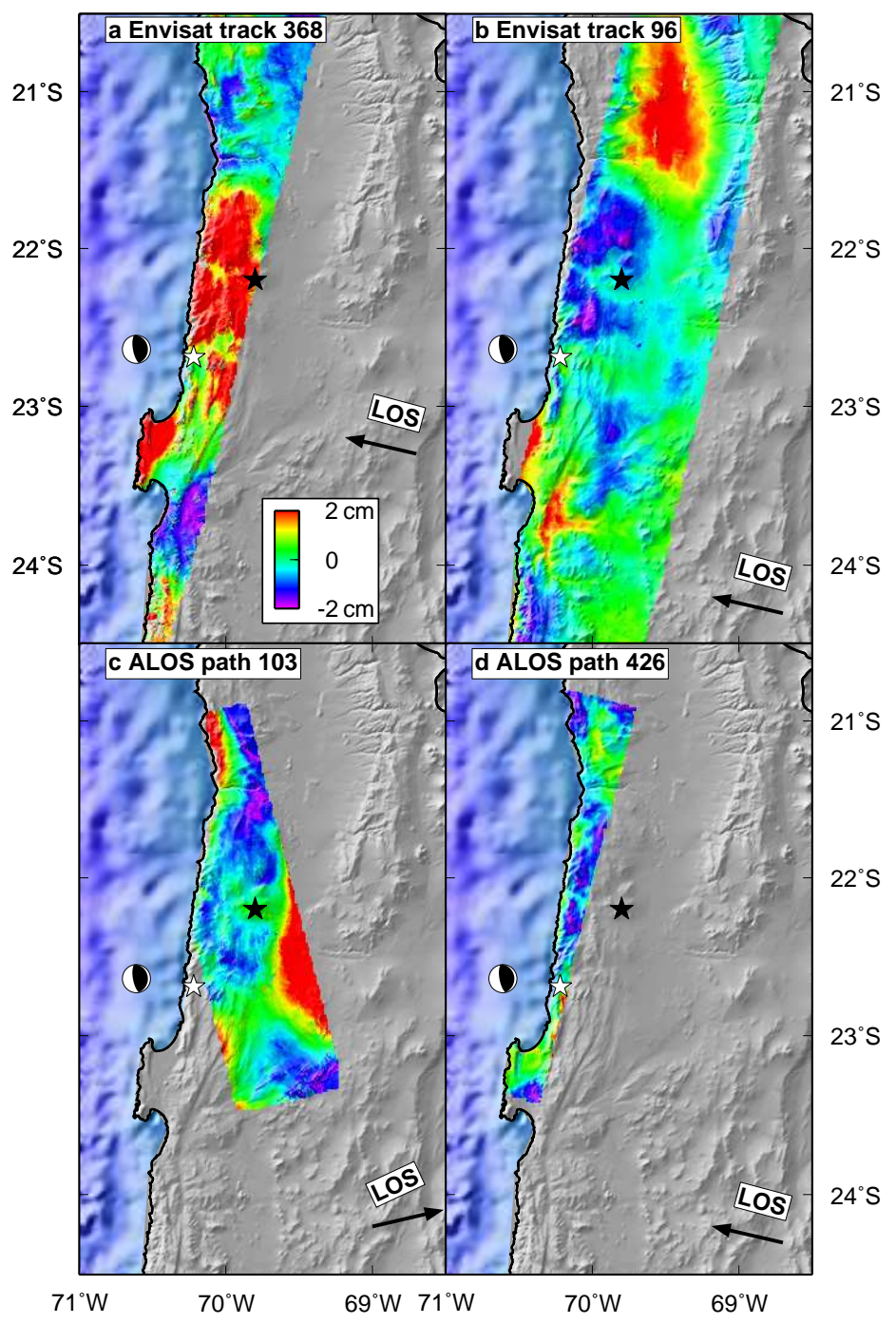

Fig. 5. InSAR residual interferograms (original data is in Figure 2) from our best fit joint model for the 2007 mainshock plotted over shaded topography and bathymetry . RMS misfits between data and the three models are as follows for each orbital track: track 368 (a): $1.5 \mathrm{~cm}$; track 96 (b): $0.8 \mathrm{~cm}$; path 103 (c): $1.5 \mathrm{~cm}$; and path 426 (d): $0.9 \mathrm{~cm}$. The USGS hypocenter location is shown as the black star, the DGF solution is the white star and the focal mechanism is from the Global CMT catalog. 


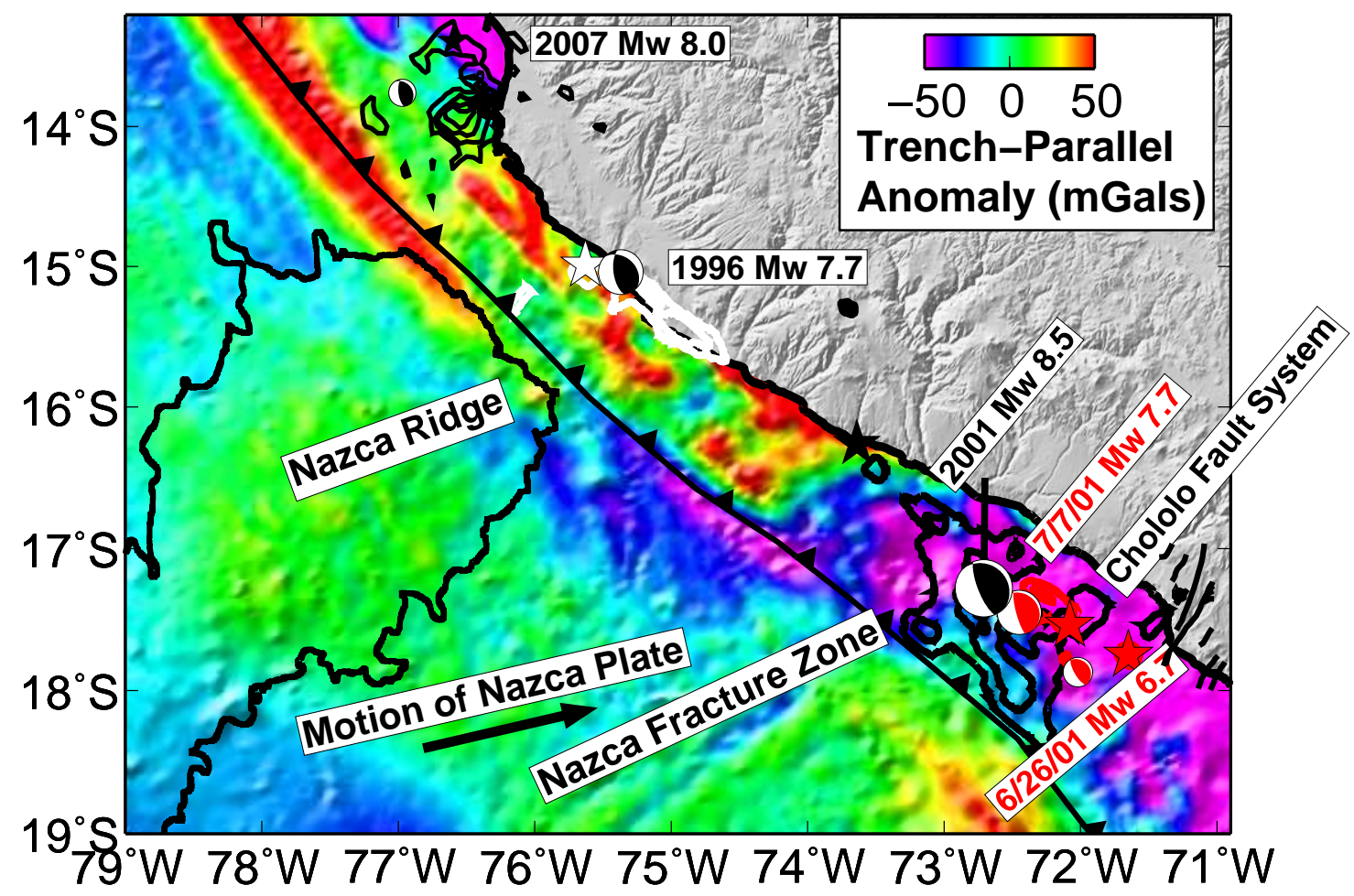

Fig. 6. Trench-Parallel Gravity Anomaly (TPGA) calculated for southern Peru using a method similar to (Song and Simons, 2003) is shown in color. In the text, we discuss the relation between TPGA and the plotted contours of slip, hypocenters and Global CMT locations and mechanisms from recent large earthquakes in the region. The off-shore Nazca Ridge is outlined by the $-3000 \mathrm{~m}$ bathymetric contour and the off-shore Nazca Fracture Zone, suggested by Robinson et al. (2006) to influence the slip distribution of the 2001 earthquake, is identified. The on-shore Chololo Fault System is shown by a series of black lines and is labeled (Audin et al., 2008). The coseismic slip distributions from the 1996 and 2001 earthquakes are from Pritchard et al. (2007) and from the 2007 earthquake is from Pritchard and Fielding (2008). 


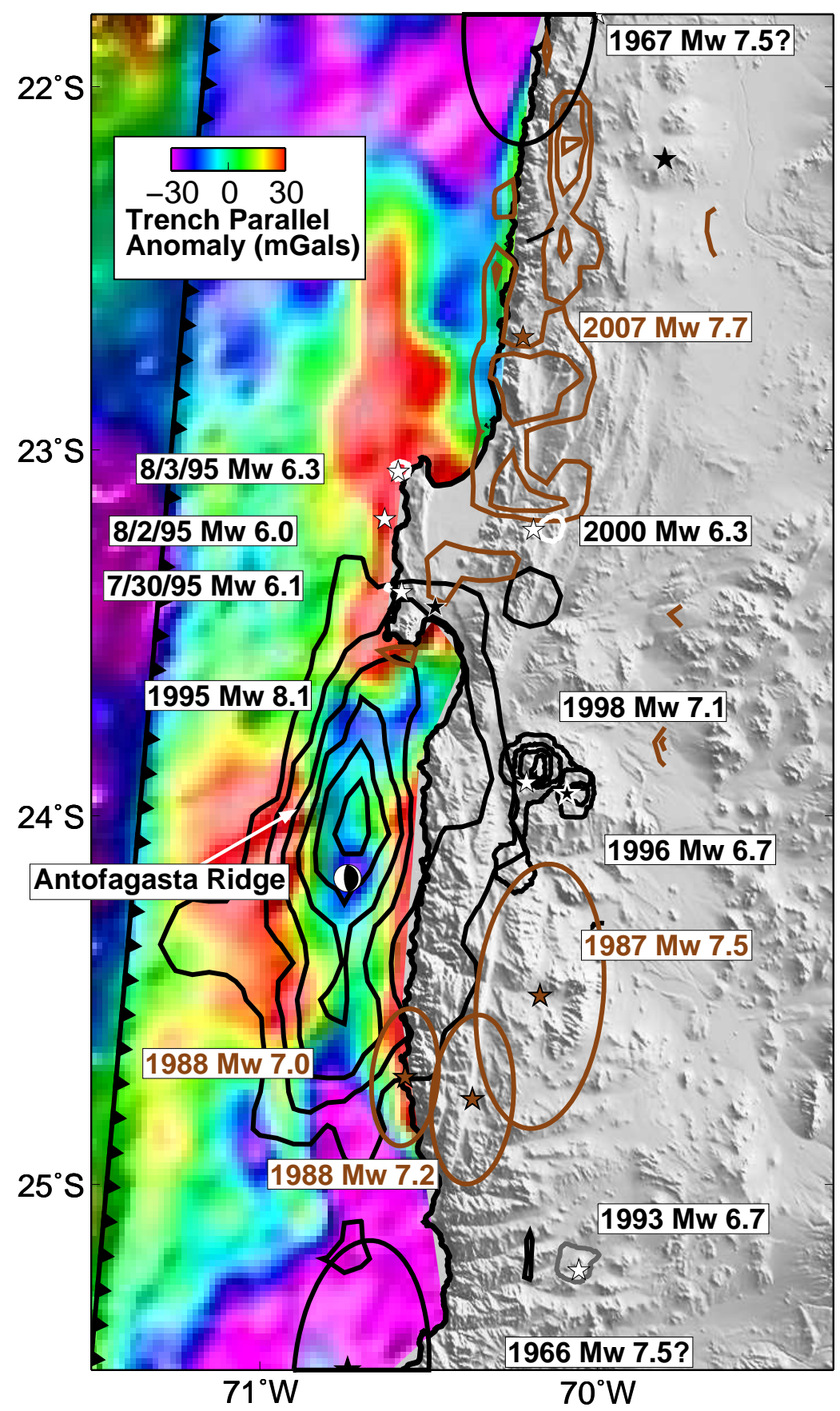

Fig. 7. Trench-Parallel Gravity Anomaly (TPGA) calculated for northern Chile using a method similar to Song and Simons (2003) is shown in color. In the text, we discuss the relation between TPGA and the plotted contours of slip, hypocenters and Global CMT locations and mechanisms from recent large earthquakes in the region. Information on the earthquake coseismic slip distributions and ellipses is in the caption to Figure 11. The off-shore Antofagasta Ridge is labeled (von Huene and Ranero, 2003) and the on-shore east-west (E-W) reverse faults of (Allmendinger et al., 2005a) are plotted, although only one lies within the latitude range of the image. 


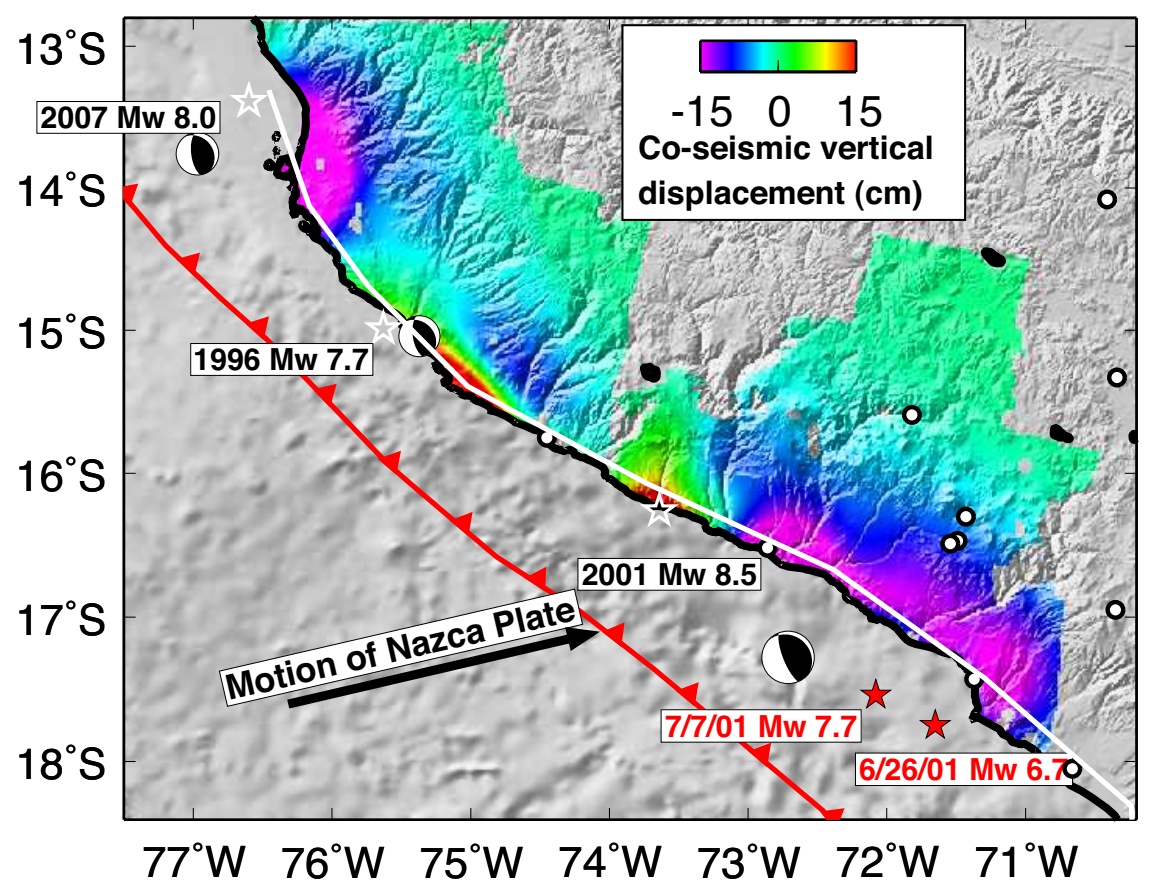

Fig. 8. Predicted vertical deformation from our models of the three Peruvian subduction zone earthquakes plotted over shaded relief. The white line marks the position of the profile through the vertical displacement fields and topography as shown in Figure 10. The white circles show the GPS stations with displacement data for the $2001 M_{w} 8.5$ earthquake (Pritchard et al., 2007). 


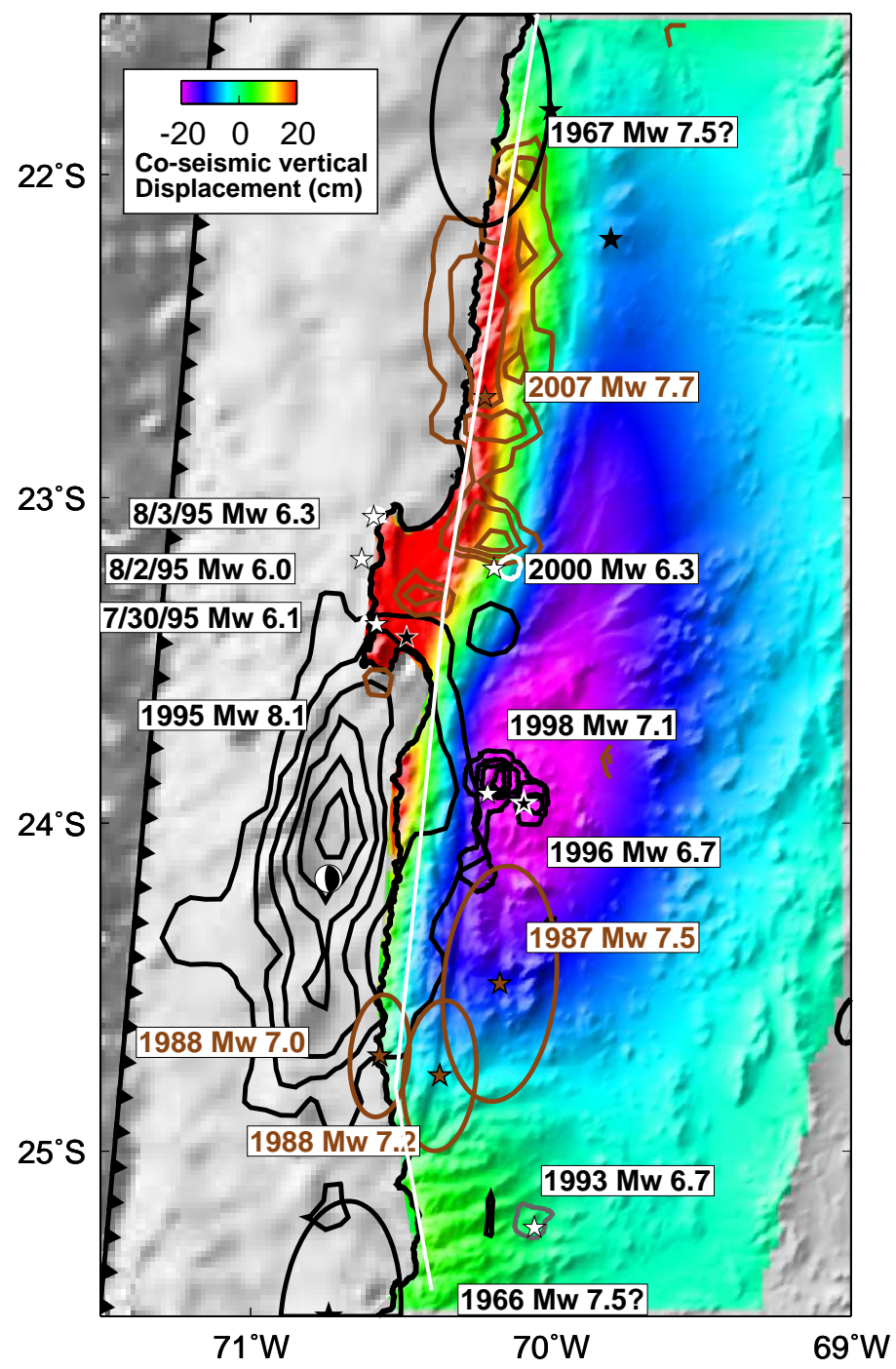

Fig. 9. Predicted vertical deformation from our models of the three northern Chile subduction zone earthquakes plotted over shaded relief. The white line marks the position of the profile through the vertical displacement fields and topography as shown in Figure 10. Information on the earthquake coseismic slip distributions and ellipses is in the caption to Figure 11. 


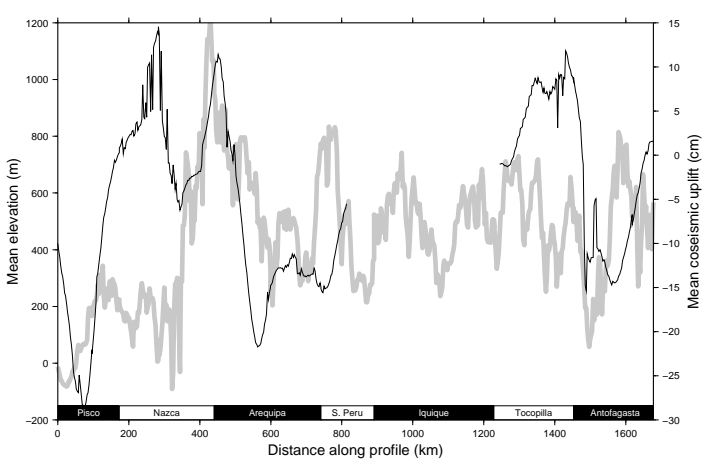

Fig. 10. Mean elevation (gray line) and composite coseismic uplift (black line) along a swath profile through coastal regions of central-southern Peru and northern Chile. The elevation and uplift data were averaged along seven parallel profiles, centered on the white line shown in Figure 8 and 9. Thus, the elevation profile samples some shallow offshore bathymetry, while the uplift profile can only sample onshore locations. The alternating black and white bars at the base of the graph indicate the approximate positions of the seismic segments referenced in the text. 


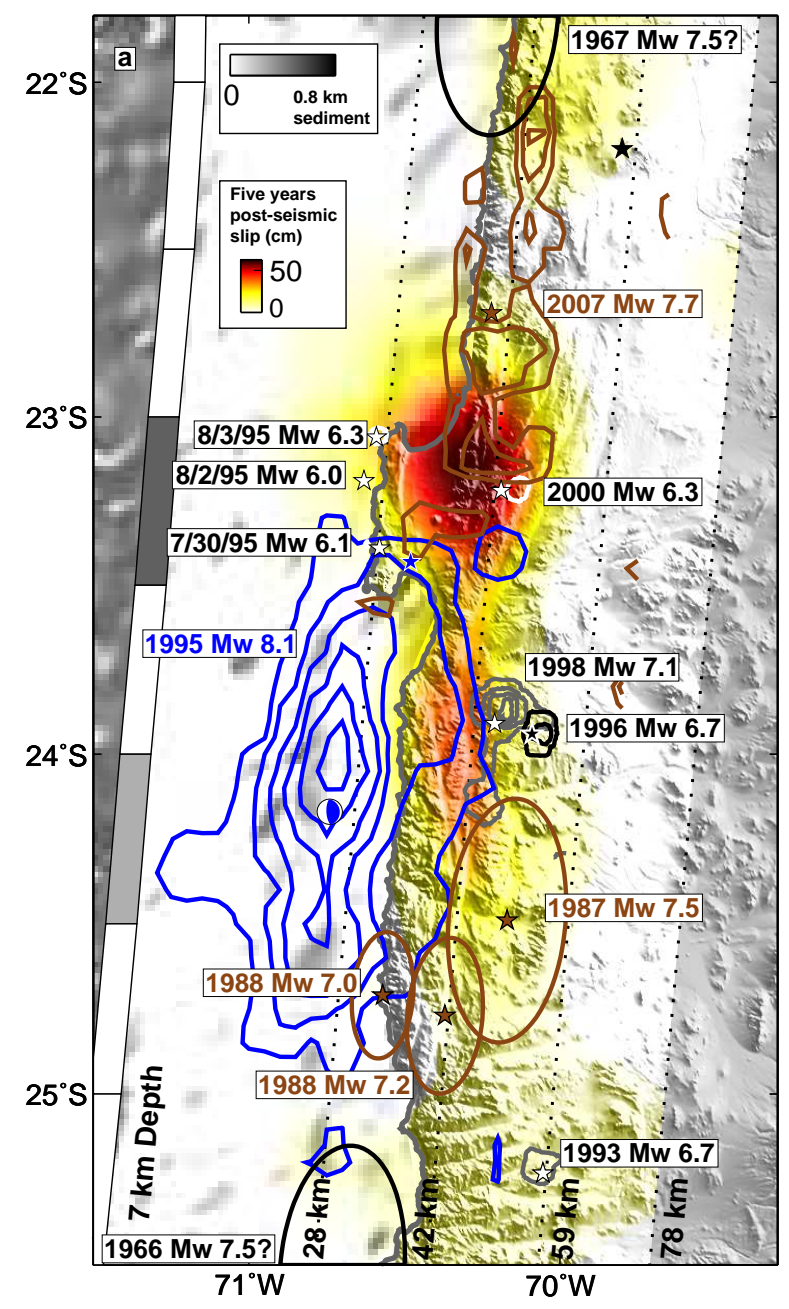

Fig. 11. Magnitude of slip on the fault interface (color) in the northern Chile subduction zone from aseismic slip from 1995-2000 (Pritchard and Simons, 2006) and earthquakes with $M_{w}>6.0$ since 1987 over shaded topography. Contours of coseismic slip from the 1995 mainshock ( $1 \mathrm{~m}$ interval), and aftershocks $\left(M_{w}>6\right)$ between 1995-2000 (0.5 m interval) are from Pritchard et al. (2006). The slip distribution for the 2007 Tocopilla earthquake is from the joint inversion of this study ( $1 \mathrm{~m}$ interval). The brown ellipses with no contours are from earthquakes in the 1980's and are scaled assuming a constant stress drop for all events of $1.4 \mathrm{MPa}$ (Pritchard et al., 2006 ), and a length to width aspect ratio of 2 . The approximate rupture locations of the 1966 and 1967 earthquakes are from Delouis et al. (1997). Depths on the fault interface are for the 1995 earthquake (black dotted lines labeled at bottom), but because some of the other events have slightly different dips, they might be a few $\mathrm{km}$ off of the reference depths. The trench location is shown as a series of boxes showing the amount of sediment in the trench (Figure 1), and the coastline is a thick gray line. 

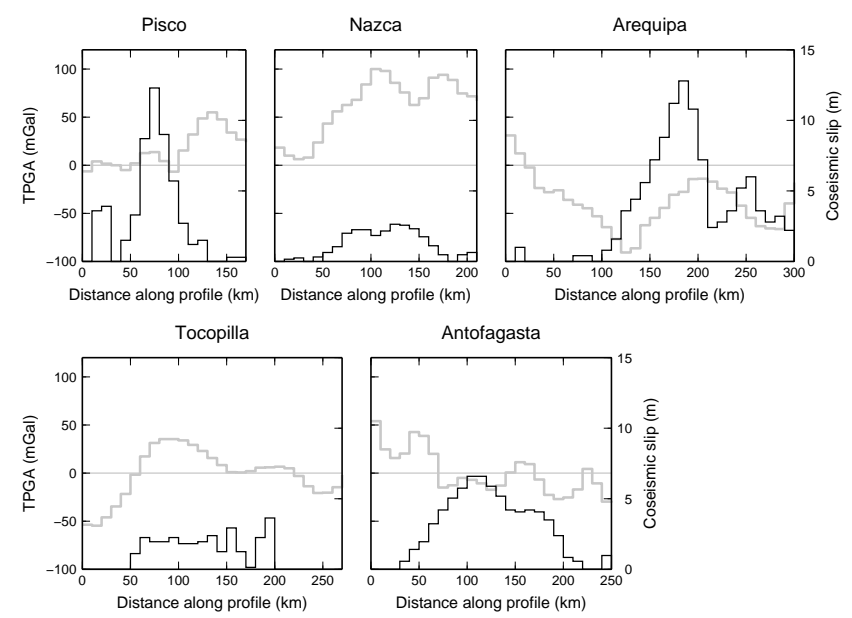

Fig. 12. Relationship between trench parallel gravity anomaly (TPGA, left axis, gray lines) and coseismic slip magnitude (right axis, black lines) for 5 of the 6 studied earthquakes. The horizontal gray line marks the TPGA $=0$ axis. For each earthquake, the TPGA field (shown in Figure 7 and Figure 6) was resampled to the $10 \times 10 \mathrm{~km}$ grid on which the slip distribution was estimated. Profiles were extracted along the fault strike, passing through the fault patch corresponding to peak coseismic slip. In the case of the 1996 Nazca and 2007 Tocopilla earthquakes, the TPGA measurements may not reflect the true gravity field, since the peak slip occurred beneath land rather than offshore. 


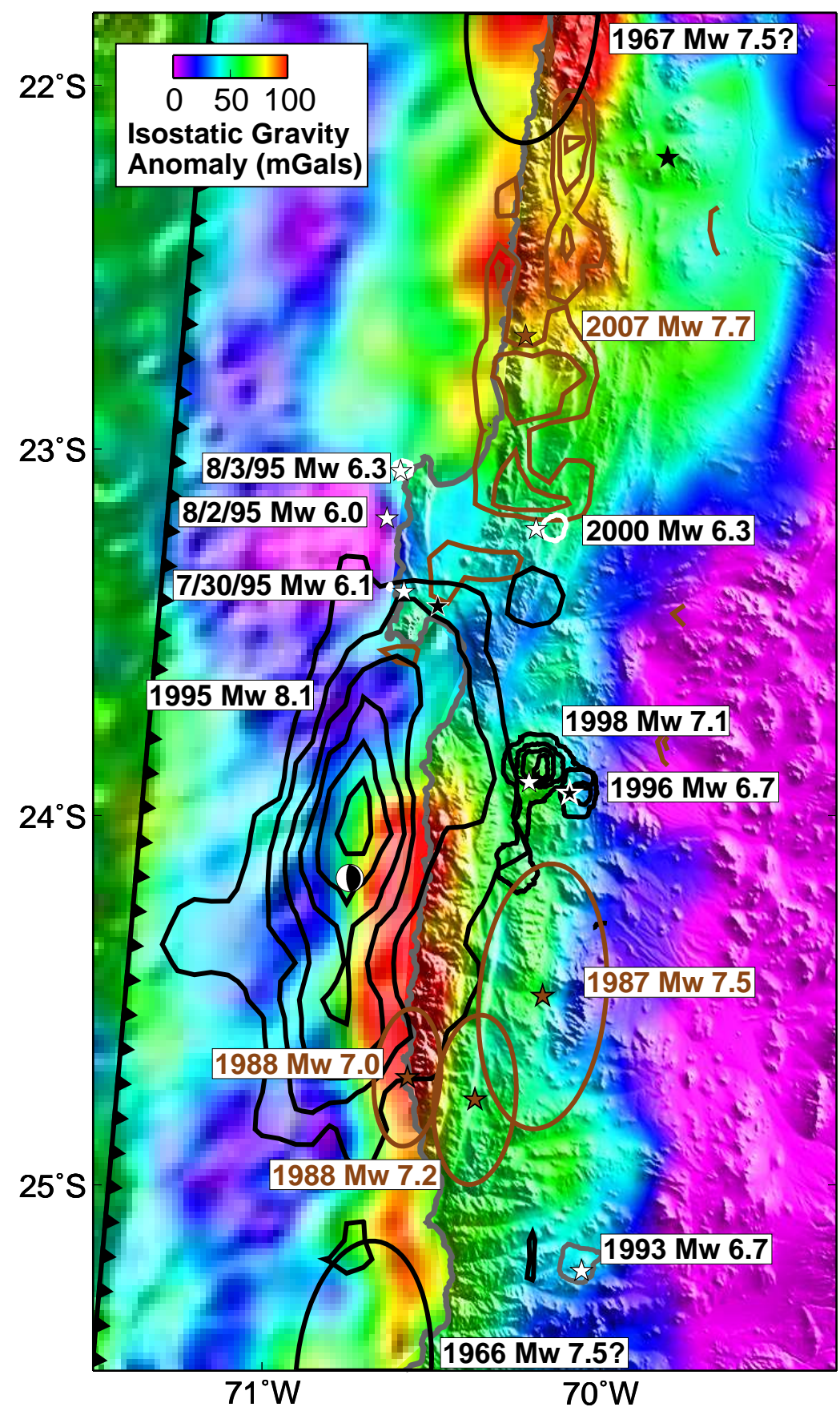

Fig. 13. Isostatic gravity Residual Anomaly (IRA) calculated for northern Chile by Schmidt and Götze (2006) is shown in color. In the text, we discuss the relation between IRA and the plotted contours of slip, hypocenters and Global CMT locations and mechanisms from recent large earthquakes in the region. Information on the earthquake coseismic slip distributions and ellipses is in the caption to Figure 11. 


\begin{tabular}{|c|c|c|}
\hline Physical property & $\begin{array}{l}\text { Effect on/correlation with } \\
\text { seismicity }\end{array}$ & References \\
\hline Crustal faults & $\begin{array}{l}\text { Interact with megathrust; } \\
\text { segment margin }\end{array}$ & $\begin{array}{l}\text { Collot et al. (2004); Audin } \\
\text { et al. (2008) }\end{array}$ \\
\hline Peninsulas & $\begin{array}{l}\text { Varied origin; mark segment } \\
\text { boundaries }\end{array}$ & $\begin{array}{l}\text { Montero (1986); Delouis } \\
\text { et al. (1997) }\end{array}$ \\
\hline Bends in coastline & $\begin{array}{l}\text { "Geometric barrier" to rup- } \\
\text { ture }\end{array}$ & Aki (1979) \\
\hline Isostatic residual anomaly & $\begin{array}{l}\text { High normal stress, hence } \\
\text { high coseismic slip }\end{array}$ & Sobiesiak et al. (2007) \\
\hline Gravity anomaly lows & Locus of high slip & $\begin{array}{l}\text { Song and Simons (2003); } \\
\text { Wells et al. (2003); Llenos } \\
\text { and McGuire (2007) }\end{array}$ \\
\hline \multirow[t]{2}{*}{ Gravity anomaly highs } & $\begin{array}{l}\text { Locus of low slip/few earth- } \\
\text { quakes }\end{array}$ & $\begin{array}{l}\text { Song and Simons (2003); } \\
\text { Wells et al. (2003) }\end{array}$ \\
\hline & $\begin{array}{l}\text { Locus of some large earth- } \\
\text { quakes }\end{array}$ & Wells et al. (2007) \\
\hline Local minima in gravity & Locus of high slip & Llenos and McGuire (2007) \\
\hline Positive gradient in gravity & Decreasing slip & Llenos and McGuire (2007) \\
\hline \multirow[t]{2}{*}{ Subducted ridges } & Segment seismicity & $\begin{array}{l}\text { Kelleher and McCann } \\
(1976)\end{array}$ \\
\hline & Aseismic slip & Beck and Nishenko (1990) \\
\hline \multirow[t]{2}{*}{ Seamounts } & Asperity & $\begin{array}{l}\text { Cloos (1992); Abercrombie } \\
\text { et al. (2001); Bilek et al. } \\
\text { (2003) }\end{array}$ \\
\hline & Impede rupture & $\begin{array}{l}\text { Cloos (1992); Bilek et al. } \\
\text { (2003); Kodaira et al. (2000) }\end{array}$ \\
\hline \multirow[t]{3}{*}{ Thick subducted sediments } & Connect asperities & Ruff (1989) \\
\hline & $\begin{array}{l}\text { Increase max. depth of seis- } \\
\text { micity }\end{array}$ & Zhang and Schwartz (1992) \\
\hline & Promote afterslip & $\begin{array}{l}\text { Pritchard } \\
(2006)\end{array}$ \\
\hline Thin subducted sediments & Limit afterslip & $\begin{array}{l}\text { Pritchard and Simons } \\
(2006)\end{array}$ \\
\hline
\end{tabular}

Table 1

Proposed physical properties influencing seismogenesis 


\begin{tabular}{lllccc} 
Satellite & Track & After image & Before image & Orbit direction & $\mathrm{B} \perp(\mathrm{m})$ \\
\hline Envisat & IM2 ${ }^{1} 96$ & 10 Dec. 2007 & 9 Apr. 2007 & Descending & 10 \\
Envisat & IM $2^{1} 368$ & 24 Nov. 2007 & 20 Oct. 2006 & Descending & 220 \\
ALOS & $426^{2}$ & 16 Dec. 2007 & 31 Oct. 2007 & Descending & 120 \\
ALOS & $103^{2}$ & 29 Nov. 2007 & 14 Oct. 2007 & Ascending & 670 \\
\hline
\end{tabular}

${ }^{1}$ IM2=Image Mode 2.

${ }^{2}$ For ALOS, "tracks" are called "paths." Most of the ALOS data we use is fine beam single polarization (FBS), but some is dual polarization (FBD). To combine FBS and FBD data interferometrically, we use the HH dual polarization channel and the FBD2FBS conversion program (available at roipac.org).

Table 2

InSAR data used in the 2007 Tocopilla earthquake slip inversion 


\begin{tabular}{|c|c|c|c|c|c|c|c|c|c|c|c|c|c|}
\hline \multicolumn{3}{|c|}{ Moment $(\mathrm{Nm})\left[M_{w}\right]$} & $\mathrm{R}^{\mathrm{a}}$ & $\mathrm{T}^{\mathrm{b}}$ & $\mathrm{V}^{\mathrm{c}}$ & $\mathrm{W}^{\mathrm{d}}$ & $\mathrm{M}^{\mathrm{e}}$ & $X^{f}$ & $\mathrm{Y}^{\mathrm{g}}$ & $\mathrm{F}^{\mathrm{h}}$ & $\mathrm{D}^{\mathrm{i}}$ & $\mathrm{H}^{\mathrm{j}}$ & $\mathrm{S}^{\mathrm{k}}$ \\
\hline Teleseismic & Geodetic & Joint & & & & & & & & & & & \\
\hline $5.2 \mathrm{e} 20[7.7]$ & $5.3 \mathrm{e} 20[7.7]$ & $5.2 \mathrm{e} 20[7.7]$ & 102 & 10 & 3.0 & 0.05 & $0.05^{\ell}$ & 28 & 13 & 10 & 23 & 39 & 5 \\
\hline
\end{tabular}

a Mean rake (degrees). Constrained to be between 70-140 degrees.

b Mean rise time (seconds). Constrained to be between 2 to 20 seconds.

${ }^{\text {c }}$ Mean rupture velocity $(\mathrm{km} / \mathrm{s})$. Constrained to be between $2.5-3.5 \mathrm{~km} / \mathrm{s}$; All mean values are for the joint inversion and calculated using weighted averages (weighted by the slip, constrained to be between 0 and $7 \mathrm{~m}$ ).

${ }^{d}$ Weight of smoothing constraint.

e Weight of moment minimization constraint.

f Number of subfaults down-dip.

g Number of subfaults along strike.

h Subfault size - same in both dimensions (in $\mathrm{km}$ ).

${ }^{\mathrm{i}}$ Fault dip (degrees).

j Hypocenter depth $(\mathrm{km})$.

${ }^{\mathrm{k}}$ Fault strike (degrees).

${ }^{\ell}$ Different moment minimization was used: For geodetic inversion, this was set to 0.0 , for the teleseismic-only and joint inversions the value was 0.05 , and the geodetic moment was used as the a priori value.

Table 3

Key parameters of the Tocopilla earthquake slip models 


\begin{tabular}{|c|c|c|c|c|c|c|}
\hline Physical & 2007 & 1996 & 2001 & 2007 & 1995 & 1998 \\
\hline property & Pisco & Nazca & Arequipa & Tocopilla & Antofagasta & Antofagasta \\
\hline Crustal faults & 0 & 0 & 1 & 0 & 0 & 0 \\
\hline Peninsulas & 0 & 0 & 1 & 1 & 1 & 0 \\
\hline Bends in coastline & 1 & 0 & 1 & 1 & 1 & $\mathrm{~N} / \mathrm{A}$ \\
\hline Isostatic residual anomaly & $?$ & $?$ & $?$ & 1 & 1 & 1 \\
\hline TPGA & 0 & 0 & 1 & * & 1 & $\mathrm{~N} / \mathrm{A}$ \\
\hline Gradient of gravity field & 1 & 1 & 1 & 1 & 1 & 1 \\
\hline Seamounts \& subducted ridge & 1 & 1 & 1 & 0 & 0 & 0 \\
\hline Long-term uplift & 0 & 0 & 0 & 0 & 0 & 0 \\
\hline
\end{tabular}

Table 4
Scorecard for different proposed physical properties that might explain seismogenesis or seismic segmentation. Key: $1=$ Correlation; $0=$ No correlation; ? = IRA was not calculated for Peru by Schmidt and Götze (2006); N/A = These parameters apply to ruptures off-shore, and these earthquakes were primarily on-shore. ${ }^{*}=$ Since the 2007 Tocopilla earthquake was mostly under land, we can not calculate the TPGA for most of the rupture. However, the slip avoided the region of positive TPGA just north of the Mejillones Peninsula. 